\title{
Intake of Lactobacillus delbrueckii (pExu:hsp65) Prevents the Inflammation and the Disorganization of the Intestinal Mucosa in a Mouse Model of Mucositis
}

\author{
Fernanda Alvarenga Lima Barroso ${ }^{1,+}$, Luís Cláudio Lima de Jesus ${ }^{1,+}$, Camila Prosperi de Castro ${ }^{1}$, \\ Viviane Lima Batista ${ }^{1}$, Ênio Ferreira ${ }^{2}$, Renata Salgado Fernandes ${ }^{3}$, André Luís Branco de Barros ${ }^{3}$, \\ Sophie Yvette Leclerq ${ }^{4}$, Vasco Azevedo ${ }^{1}$, Pamela Mancha-Agresti 1,5,* and Mariana Martins Drumond ${ }^{1,6, *}$
}

1 Laboratório de Genética Celular e Molecular (LGCM), Departamento de-Genética, Ecologia e Evolução, Instituto de Ciências Biológicas, Universidade Federal de Minas Gerais (UFMG),

Belo Horizonte 31270-901, Brazil; fernanda_alima@hotmail.com (F.A.L.B.); lc.luiis@yahoo.com.br (L.C.L.d.J.); camilaprosperic@gmail.com (C.P.d.C.); vivianelimabio@gmail.com (V.L.B.); vasco@icb.ufmg.br (V.A.)

2 Departamento de Patologia Geral, Instituto de Ciências Biológicas, Universidade Federal de Minas Gerais, Belo Horizonte 31270-901, Brazil; enioferreira@icb.ufmg.br

3 Departamento de Análises Clínicas e Toxicológicas, Faculdade de Farmácia, Campus da UFMG, Universidade Federal de Minas Gerais, Cidade Universitária, Belo Horizonte 31270-901, Brazil; renatasalgadof@yahoo.com.br (R.S.F.); brancodebarros@yahoo.com.br (A.L.B.d.B.)

4 Laboratório de Inovação Biotecnológica, Fundação Ezequiel Dias (FUNED), Belo Horizonte 30510-010, Brazil; sodris2003@gmail.com

check for

updates

Citation: Barroso, F.A.L.; de Jesus, L.C.L.; de Castro, C.P.; Batista, V.L.;

Ferreira, Ê.; Fernandes, R.S.;

de Barros, A.L.B.; Leclerq, S.Y.; Azevedo, V.; Mancha-Agresti, P.; et al. Intake of Lactobacillus delbrueckii (pExu:hsp65) Prevents the Inflammation and the Disorganization of the Intestinal Mucosa in a Mouse Model of Mucositis. Microorganisms 2021, 9, 107. https://doi.org/10.3390/ microorganisms 9010107

Received: 2 November 2020 Accepted: 30 November 2020 Published: 5 January 2021

Publisher's Note: MDPI stays neutral with regard to jurisdictional clai$\mathrm{ms}$ in published maps and institutional affiliations.

Copyright: (C) 2021 by the authors. Licensee MDPI, Basel, Switzerland. This article is an open access article distributed under the terms and conditions of the Creative Commons Attribution (CC BY) license (https:// creativecommons.org/licenses/by/ $4.0 /)$.
5 Faculdade de Minas-Faminas-BH, Medicina, Belo Horizonte 31744-007, Brazil

6 Centro Federal de Educação Tecnológica de Minas Gerais (CEFET/MG),

Departamento de Ciências Biológicas, Belo Horizonte 31421-169, Brazil

* Correspondence: p.mancha.agresti@gmail.com (P.M.-A.); mmdrumond@gmail.com (M.M.D.); Tel.: +55-31-99817-5004 (P.M.-A.); +55-31-99222-2761 (M.M.D.)

$+\quad$ These authors contributed equally to this work.

Abstract: 5-Fluorouracil (5-FU) is an antineoplastic drug that causes, as a side effect, intestinal mucositis, acute inflammation in the small bowel. The Heat Shock Protein (Hsp) are highly expressed in inflammatory conditions, developing an important role in immune modulation. Thus, they are potential candidates for the treatment of inflammatory diseases. In the mucositis mouse model, the present study aimed to evaluate the beneficial effect of oral administration of milk fermented by Lactobacillus delbrueckii CIDCA 133 (pExu:hsp65), a recombinant strain. This approach showed increased levels of sIgA in the intestinal fluid, reducing inflammatory infiltrate and intestinal permeability. Additionally, the histological score was improved. Protection was associated with a reduction in the gene expression of pro-inflammatory cytokines such as Tnf, Il6, Il12, and Il1b, and an increase in Il10, Muc2, and claudin 1 (Cldn1) and 2 (Cldn2) gene expression in ileum tissue. These findings are corroborated with the increased number of goblet cells, the electronic microscopy images, and the reduction of intestinal permeability. The administration of milk fermented by this recombinant probiotic strain was also able to reverse the high levels of gene expression of Tlrs caused by the 5-FU. Thus, the rCIDCA 133:Hsp65 strain was revealed to be a promising preventive strategy for small bowel inflammation.

Keywords: recombinant probiotics; DNA delivery; intestinal mucositis; inflammation; technetium99m; bacterial translocation; gene expression

\section{Introduction}

Radio- and chemotherapy and the combination of both are widely used for cancer treatment. 5-Fluorouracil (5-FU) is one of the main chemotherapeutic drugs used to treat several types of cancer. This drug is responsible for several adverse effects, such as mucositis, an inflammatory process that affects the entire digestive tract, causing abdominal 
pain, nausea, and diarrhea, which is the main limiting factor for the continuity and, consequently, efficacy of cancer treatment [1-3].

Many strategies have been studied, such as the administration of amino acids [4,5], vitamins [6], antioxidants [7], fatty acids [8,9], and, last but not least, the administration of probiotics, mainly lactic acid bacteria (LAB), such as lactobacilli $[10,11]$, to alleviate the mucositis symptoms. The protective effects of probiotics on the intestinal barrier have been related to their influence on innate and adaptive immunity. Their ability to regulate Tolllike receptors (Tlrs) [12] and customize the composition and activity of the gut microbiota leads them to show many immune and non-immune protective mechanisms [13].

The treatment of intestinal diseases, such as colitis and mucositis, with wild-type probiotics has been reported to show promising results [14-17]. The probiotics display promising results, as demonstrated in different animal models; however, positive results are more limited when treating human inflammatory diseases. For that reason, more studies should be performed.

Thereby, based on these experiences and along with increasing the beneficial characteristics of probiotics, studies on many strains that express or encode different proteins with anti-inflammatory activities as promising candidates for the treatment of other pathological conditions, especially inflammatory bowel disorders, have been performed [15,18-22]. In this context, studies have been developed using the microbial $65 \mathrm{kDa}$ heat shock protein (Hsp65) of Mycobacterium leprae (homolog to mammalian Hsp60) in many different animal disease models, to evaluate either prevention or treatment. For instance, to evaluate the effect of this protein in tuberculosis disease, mice [23] and calves [24] were used. Mouse models were used to study colitis [25], encephalomyelitis [26], lupus [27], and atherosclerosis [28], among others, with excellent outcomes, thus demonstrating the relevance of the Hsp65 protein as a good candidate for treatment and therapeutic uses.

Hsp proteins constitute about $5 \%$ of all intracellular proteins of prokaryotic and eukaryotic organisms, with high structural homology between bacterial and mammalian Hsps [29]. They participate in protein folding, degradation of misfolded protein, acting as intracellular chaperones, avoiding undesirable protein aggregation during folding and subunit assemblage [30,31], and provide their clearance and recycling [32,33]. The Hsps are ubiquitous antigens expressed as housekeeping proteins [34] and are up-regulated in inflamed tissues, responsible for responding to stressor agents, such as toxins, oxidative injury, inflammatory processes, and infections, leading the reestablishment of homeostasis [35-37].

Hsps, also known as stress proteins, are considered to be conserved proteins during evolution, present in all living organisms. These proteins play an essential role in molecular chaperones, interacting either with proteins tagged for degradation or with foreign polypeptide aggregation [38]. Hsps are up-regulated when cells face stressful situations [39-41], such as an infectious disease, presenting immunoregulatory activities [42], and also participate in cell survival signaling pathways [43]. Additionally, these molecules are considered natural adjuvants since they stimulate internalization by scavenger receptors and even the presentation of antigens through Major histocompatibility complex (MHC) molecules, inducing the production of chemokines, pro-inflammatory cytokines, as well as the production of nitric oxide by macrophages and dendritic cells $[42,44,45]$.

The precise role of Hsps in Inflammatory Bowel Diseases (IBDs) is still not clear. Miao and colleagues [46] correlated the severity of the disease with elevated levels of Hsp70 in human patients with ulcerative colitis. In patients with IBD, autoantibodies were detected to Hsp60 and Hsp70, linking the disease pathogenesis to the cross-reactivity between Hsps from eukaryotic and prokaryotic organisms [47].

Recombinant Lactococcus lactis NCDO2118, producing Hsp65 protein, was developed by our research group [48]. This recombinant strain showed promising results when it was tested in colitis [25] and experimental autoimmune encephalomyelitis (EAE) [26] mouse models. Thus, the immunomodulatory and anti-inflammatory action of the Hsps molecules was shown. 
Regarding the mechanisms associated with the beneficial effects of Hsp65, GomesSantos et al. [25] used the engineered L. lactis mentioned above, associated with the protection of the gut with increased Il10 levels in the colon and an expansion, in spleen and mesenteric lymph nodes, of $\mathrm{CD}^{+}{ }^{+} \mathrm{Foxp}^{+}$and $\mathrm{CD} 4^{+} \mathrm{LAP}^{+}$regulatory $\mathrm{T}$ cells, possibly in a dependent effect on Tlr2 and Il10. They also showed a reduction in pro-inflammatory cytokines and maybe the same role could be observed in mucositis since both are injuries of the intestinal tract.

Based on these promising results for heterologous protein production by L. lactis, our research group developed a broad-range plasmid called pExu [49] to be used as a DNA vaccine vector. In this approach, the host cells are in charge of protein production, with $\mathrm{LAB}$ as the delivery vehicle.

Thus, based on the beneficial action of Hsp65 protein in different diseases, and considering the protective effect of milk fermented by the L. delbrueckii CIDCA 133 strain in an intestinal mucositis mouse model previously reported by De Jesus et al. [17], the present study aims to investigate the therapeutic/protective and immunomodulatory effect of recombinant L. delbrueckii CIDCA 133 (pExu:hsp65) on the harmful effects of 5-FU in the intestinal epithelium.

\section{Materials and Methods}

\subsection{Bacterial Strains and Plasmids}

Escherichia coli (E. coli) Top10 (Invitrogen) were grown aerobically in Luria-Bertani medium (LB) (Acumedia Lansing, MI, USA) at $37^{\circ} \mathrm{C}$ with vigorous shaking. Lactobacillus delbrueckii subsp. Lactis CIDCA 133, belonging to the culture collection of the Centro de Investigación y Desarrollo en Criotecnología de Alimentos (CIDCA, Facultad de Ciencias Exactas, Universidad Nacional de La Plata, Argentina), were grown in de Man, Rogosa, and Sharpe (MRS) broth (Kasvi, São José dos Pinhais, Brazil) at $37^{\circ} \mathrm{C}$ for $16 \mathrm{~h}$ in microaerobiosis. When necessary, this medium was supplemented with $2.5 \mu \mathrm{g} / \mathrm{mL}$ of erythromycin (SigmaAldrich, St Louis, MO, USA) for the growth of recombinant strains, L. delbrueckii CIDCA 133 (pExu:empty), and L. delbrueckii CIDCA 133 (pExu:hsp65).

\subsection{DNA Vaccine Construction: Recombinant L. delbrueckii CIDCA 133 (pExu:hsp65)}

To construct the DNA vaccine, the functional pVax:hsp65 plasmid [50] was digested with 10 units of BamHI (Biolabs, England) and 20 units of NotI (Invitrogen, Carlsbad, CA, USA) restriction enzymes. A $3.3 \mathrm{~Kb}$ fragment corresponding to the Mycobaterium leprae hsp65 gene was obtained with cytomegalovirus (CMV) intron A. The same restriction enzymes were used to digest the empty pExu plasmid [49]. The insert and the digested vector were purified using a commercial kit (IllustraTM GFXTM PCR DNA, GE Healthcare, Chicago, IL, USA). The ligation was performed with T4 DNA ligase (Invitrogen, Carlsbad, CA, USA) for $16 \mathrm{~h}$ at $4{ }^{\circ} \mathrm{C}$. After this time, pExu:hsp 65 construction was established by transformation into E. coli Top 10 by electroporation $(1800 \mathrm{~V}, 200 \Omega$ resistance and $25 \mu \mathrm{F}$ capacitance pulse in a $0.2 \mathrm{~cm}$ cuvette), using the Gene Pulser Xcell ${ }^{\mathrm{TM}}$ Electroporation System (Bio-Rad, Richmond, CA, USA). The transformants were plated in a solid medium supplemented with $500 \mu \mathrm{g} / \mathrm{mL}$ of erythromycin to select resistant colonies.

Plasmids from E. coli (pExu:hsp65) were isolated by alkaline lysis as described by Green and Sambrook [51], and this construction was confirmed by enzymatic digestion (NotI and BamHI). The gene expression was confirmed using a Chinese hamster ovarian cell line [Flp$\mathrm{In}^{\mathrm{TM}}$-CHO (Invitrogen, Carlsbad, CA, USA)] (CRL 12023) from ATCC and Lipofectamine 2000 (Invitrogen, Carlsbad, CA, USA) as described by Coelho-Rocha et al. [52]. Briefly, eukaryotic cells were transfected with $4 \mu \mathrm{g}$ of sterile pExu:gfp (positive control); pExu:hsp65; pExu:empty [49]; or any plasmid for the negative control. The immunohistochemical reaction checked the eukaryotic cells' protein expression. Thereby, forty-eight hours posttransfection, the transfected eukaryotic cells were fixed with $4 \%(w / v)$ of paraformaldehyde (Sigma-Aldrich, St. Louis, MO, USA) in phosphate-buffered saline (PBS, $0.1 \mathrm{M}$ ) for $15 \mathrm{~min}$ and permeabilized with $0.1 \%(w / v)$ Triton $\times 100$ (Vetec, Rio de Janeiro, Brazil) in PBS 
for $10 \mathrm{~min}$. The cells were incubated for one hour with monoclonal anti-Hsp65 (D17J) (Invitrogen, Carlsbad, CA, USA), diluted 1/50 in 1\% bovine serum albumin (BSA; SigmaAldrich, St. Louis, MO, USA) at room temperature. The cells were washed with $0.1 \mathrm{M}$ PBS three times and then incubated with the secondary antibody, goat anti-mouse IgG $\left(\mathrm{H}+\mathrm{L}\right.$ ) Alexa Fluor ${ }^{\circledR} 488$ (Life Technologies, Carlsbad, CA, USA, 4 rg/mL, diluted 1/500 in PBS/BSA 1\%) for $1 \mathrm{~h}$ in reduced light conditions. At the same time, 4,6'-diamidino-2phenylindole (DAPI, Invitrogen, Carlsbad, CA, USA, $2 \mu \mathrm{g} / \mathrm{mL}$, diluted 1/300) was used for cell nucleus staining. Samples were mounted and the images were captured using a Zeiss LSM 510 META inverted confocal laser-scanning microscope and collected and analyzed using Zeiss LSM Image Browser software. Duplicate transfection assays were performed.

The pExu:hsp65 functional plasmid was stabilized into L. delbrueckii CIDCA133 to develop the recombinant strain, L. delbrueckii CIDCA133 (pExu:hsp65). To this end, electrocompetent $L$. delbrueckii were transformed by electroporation $[2500 \mathrm{~V}, 200 \Omega$ resistance, and $25 \mu \mathrm{F}$ capacitance pulse in a $0.2 \mathrm{~cm}$ cuvette, Gene Pulser Xcell ${ }^{\mathrm{TM}}$ Electroporation Systems (Bio-Rad, Richmond, CA, USA)] with $1 \mu \mathrm{g} / \mathrm{mL}$ of pExu:hsp65 plasmid. The transformants were plated on MRS (Kasvi, São José dos Pinhais, Brazil) agar (1.5\%, Acumedia ${ }^{\circledR}$, Indaiatuba, Brazil) plates supplemented with $2.5 \mu \mathrm{g} / \mathrm{mL}$ of erythromycin for $48 \mathrm{~h}$ at $37^{\circ} \mathrm{C}$. Plasmids from L. delbrueckii CIDCA 133 (pExu:empty and pExu:hsp65) were isolated by glass beads (Sigma Aldrich, St. Louis, MO, USA) using Precellys 24 Homogenizer ${ }^{\circledR}$ (1 cycle, $6500 \mathrm{rpm}, 15 \mathrm{~s}$ ) (Bertin Technologies, Montigny Le Bretonneux, France). After that, the alkaline lysis protocol and enzymatic digestion were carried out.

\subsection{Dairy Formulation}

Fifty microliters of bacteria culture were inoculated into $15 \mathrm{~mL}$ of milk medium (12\% skimmed milk ( $w / v)$ (Itambé, Belo Horizonte, Brazil), 2\% glucose $(w / v)$ (Labsynth, São Paulo, Brazil), 1.2\% (w/v) yeast extract (Kasvi, São José dos Pinhais, Brazil) with $2.5 \mu \mathrm{g} / \mathrm{mL}$ of erythromycin) for $16 \mathrm{~h}$ at $37^{\circ} \mathrm{C}$ without shaking to prepare the fermented milk. After that, the culture was diluted 100 times in sterilized milk medium and then administered ad libitum to the mice. To avoid bacterial decantation and clogging, this process was done every $12 \mathrm{~h}$. This beverage and standard chow diet were administered ad libitum for 13 days. The colony-forming units (CFUs) (viable bacteria) administrated to the mice were analyzed by the pour plate method (MRS agar medium with erythromycin, when required), after incubation for $16 \mathrm{~h}$ at $37^{\circ} \mathrm{C}$. The CFUs calculated were $3.5 \times 10^{6} \mathrm{CFU} / \mathrm{mL}$ for L. delbrueckii (pExu:hsp65), and $5 \times 10^{6}$ for L. delbrueckii (pExu:empty).

\subsection{Mouse Handling and Experimental Design}

Conventional BALB/c male, 6 weeks old, weighing 21-24 g, were provided by the animal facility of the Centro de Bioterismo (CEBIO) of the Institute of Biological Sciences, at the Federal University of Minas Gerais (Belo Horizonte, Minas Gerais, Brazil). The animals were kept in polycarbonate open boxes under controlled conditions: temperature around $22 \pm 2{ }^{\circ} \mathrm{C}, 12 \mathrm{~h} \mathrm{light/dark}$ cycle, humidity of $55 \pm 10 \%$, water $24 \mathrm{~h}$ before experiments, and standard chow diet available ad libitum. All procedures were done in compliance with the Brazilian Society of Sciences in Laboratory Animals (SBCAL) guidelines and were approved by the Animal Experimentation Ethics Committee (CEUA-UFMG, Protocol $\mathrm{n}^{\circ}$ 66/2019, 27 May 2019). The protocol complied with the guidelines recommended by the Institute of Laboratory Animal Resources for the care and use of laboratory animals.

Mice were randomly divided into four different experimental groups ( $n=8 /$ group): negative control (CTL); CIDCA 133 (pExu:empty), hereafter called rCIDCA 133; positive control of mucositis (MUC); and CIDCA 133 (pExu:hsp65), hereafter rCIDCA133:Hsp65. Animals were orally fed daily either with non-fermented milk supplemented with erythromycin $(2.5 \mu \mathrm{g} / \mathrm{mL})(\mathrm{CTL}$ and MUC) or with fermented milk by recombinant strains rCIDCA 133 or rCIDCA133:Hsp65 containing erythromycin $(2.5 \mu \mathrm{g} / \mathrm{mL})$ over 13 days. On the 10th day, all groups except the CTL group received a single intraperitoneal (i.p) injection of 5-FU $\left(300 \mathrm{mg} / \mathrm{kg}\right.$ ) (Fauldfluor ${ }^{\circledR}$, Libbs, São Paulo, Brazil) to induce mucositis, following the same 
protocol of our previous report [17]. The control group (CTL) received saline solution (i.p). Seventy-two hours after administration, all animals were anesthetized with a ketamine $(80 \mathrm{mg} / \mathrm{kg})$ and xylazine $(16 \mathrm{mg} / \mathrm{kg}$ ) mixture (Agener União, Embu-Guaçu, Brazil) and euthanized. The ileum section of the small intestine and the blood of mice were collected for analysis. Furthermore, bodyweight and milk and feed intake were assessed daily.

\subsection{Intestinal Permeability Evaluation}

The intestinal permeability (IP) can assess gut mucosa integrity. A $0.1 \mathrm{~mL}(18.5 \mathrm{MBq})$ sample of diethylenetriamine penta-acetic acid (DTPA) solution labeled with technetium$99 \mathrm{~m}$ (99mTc-DTPA) was administrated by gavage to the mice on the 13th day of treatment, as previously reported [53]. Four hours later, the mice were anesthetized as previously described. Approximately $200 \mu \mathrm{L}$ blood was collected, weighed, and the radioactivity level in the blood was determined in an automated gamma counter (PerkinElmer Wallac Wizard 1470-020 Gamma Counter, Waltham, MA, USA). A standard dosage containing the same injected amount was counted simultaneously in a separate tube, which was defined as $100 \%$ radioactivity. The results were expressed as the percentage of injected dose per gram $(\% \mathrm{ID} / \mathrm{g})$ of blood: counts per $\mathrm{min}=(\mathrm{cpm}$ of blood $/ \mathrm{cpm}$ of the administered dose $) \times 100$. where cpm represents the count of radioactivity per minute.

\subsection{Bacterial Translocation Study}

Bacterial translocation (BT) was evaluated using radiolabeled E. coli, as previously reported [54]. Briefly, a culture of E. coli $\mathrm{ATCC}^{\circledR} 10536^{\mathrm{TM}}$ was grown overnight in soybean casein medium agar. Then the grown cells were transferred to $10 \mathrm{~mL}$ of sterile $0.9 \%(w / v)$ $\mathrm{NaCl}$ solution. Two milliliters of bacterial solution $\left(10^{8} \mathrm{CFU} / \mathrm{mL}\right)$ were incubated with $1 \mathrm{~mL}$ of stannous chloride solution $(580 \mathrm{mM}, \mathrm{pH} 7.0)$ at $37^{\circ} \mathrm{C}$ for $10 \mathrm{~min}$. After incubation, $99 \mathrm{mTc}(37.0 \mathrm{MBq})$ was added, and the mixture was kept at $37^{\circ} \mathrm{C}$ for $10 \mathrm{~min}$. The tubes were then centrifuged at $3000 \times g$ for $25 \mathrm{~min}$, and $100 \mathrm{~mL}$ of either supernatant and resuspended precipitate in saline were used to measure the radioactivity using a dose calibrator (Capintec CRCw-15R Dose Calibrator; CAPINTEC, Inc., Ramsey, NJ, USA). This procedure was done in triplicate. The percent of $99 \mathrm{mTc}$ incorporated into the bacterial cells was determined using the following equation: \% labeled bacteria $=(\mathrm{cpm}$ of precipitate $/(\mathrm{cpm}$ of precipitate $+\mathrm{cpm}$ of supernatant $)) \times 100$. Then, the suspension of $99 \mathrm{mTc}-E$. coli $\left(10^{8} \mathrm{CFU} / \mathrm{mL}\right)$ was used for the bacterial translocation study. To this end, $0.1 \mathrm{~mL}(1.8 \mathrm{MBq})$ of $99 \mathrm{mTc}-E$. coli were administrated by gavage to all groups on the 13th day, $4 \mathrm{~h}$ before euthanasia. After this time, the animals were i.p. anesthetized as described before, the blood sample was collected, and then mice were sacrificed by cervical dislocation. Following the mesenteric lymph nodes (MLNs), blood, liver, spleen, heart, kidneys, and lungs were removed, weighed, and the level of radioactivity present in each organ was measured using an automated gamma counter (PerkinElmer Wallac Wizard 1470-020 Gamma Counter; PerkinElmer, Waltham, MA, USA). The results were expressed as counts per minute (cpm)/g of tissue.

\subsection{Histological, Morphological, and Goblet Cell Analyses}

Histological assays were done to analyze the architecture of the intestinal mucosa. After euthanasia, the small intestine was removed, and its length was measured. Then the ileum section was washed with PBS $0.1 \mathrm{M}$, rolled up, and placed into a histological cassette and immersed in a $10 \%$ neutral buffered formalin (NBF) solution [100 mL formaldehyde 37-40\%, (Synth, São Paulo, Brazil); 4 g/L HPO4Na, (Synth, São Paulo, Brazil); and 6.5 g/L $\mathrm{H}_{2} \mathrm{PO}_{4} \mathrm{Na}$ (Vetec, Rio de Janeiro, Brazil)] for $24 \mathrm{~h}$. From a paraffin block containing the samples, $4 \mu \mathrm{m}$ thick slices were cut, mounted on glass slides, and stained with hematoxylin and eosin (H\&E) or periodic acid-Schiff (PAS). To measure the depth of crypts, villus height, goblet cell number, and polymorphonuclear cell infiltrate, the selected image (H\&E and PAS) was captured by a BX41 optical microscope (Olympus, Tokyo, Japan) and analyzed using ImageJ 1.51j.8 software (NIH, Bethesda, MD, USA). Image acquisition was performed 
with a $20 \times$ magnification objective and 20 villi and 20 crypts in random fields of each mouse, images were analyzed, and the ratio of villus height/crypt depth from the intestinal epithelium was found. The study of goblet cells was performed in PAS-stained slides, where 10 field/slides were counted. Histological examination was performed using a blind score based on a system described previously by Soares et al. [55] to obtain the histological score.

\subsection{Leukocyte Count}

Blood samples were collected from the axial plexus, and the total number of leucocytes was measured by an automatic hematological counter (Bio-2900 Vet, Bioeasy, EUA). Results were expressed as the number of leukocytes per $\mu \mathrm{L}$ of the sample.

\subsection{Enzyme Assay: Intestinal Myeloperoxidase (MPO) and Eosinophil Peroxidase (EPO) Activity}

The MPO and EPO enzyme activities properly evaluate the neutrophil and eosinophil infiltration, respectively, in the intestinal mucosa [56]. These enzymes' activities were assessed in homogenate ileum tissue described previously by De Jesus et al. [17]. Briefly, $100 \mathrm{mg}$ of tissue were homogenized in $1.9 \mathrm{~mL}$ PBS 0.1 M (pH 7.4) using a tissue homogenizer (MA1102 model, Marconi, São Paulo, Brazil). The homogenate was centrifuged $(3000 \times g$ for $10 \mathrm{~min})$, then the pellets were subjected to hypotonic lysis $(1.5 \mathrm{~mL}$ of $0.2 \% \mathrm{NaCl})$. The osmolarity was restored with $1.5 \mathrm{~mL}$ of $\mathrm{NaCl} 1.6 \%$ solution supplemented with $5 \%$ glucose. Then, samples were centrifuged $(3000 \times g$ for $10 \mathrm{~min})$, and the pellet was resuspended in $0.5 \%$ hexadecyltrimethylammonium bromide (HTAB, Sigma-Aldrich, St. Louis, MO, USA) in phosphate buffer. The tissue suspension was homogenized, freeze-thawed three times in liquid nitrogen, and centrifuged for $15 \mathrm{~min}$ at $3000 \times \mathrm{g}$. The resulting supernatant was used in the colorimetric assay to measure the EPO and MPO activities. For EPO assessment, $75 \mu \mathrm{L}$ of supernatant were added to $75 \mu \mathrm{L}$ of $1.5 \mathrm{mM}$ O-phenylenediamine (OPD, SigmaAldrich, St. Louis, MO, USA), diluted in $0.075 \mathrm{mM}$ Tris- $\mathrm{HCl}$ and $6.6 \mathrm{mM} \mathrm{H}_{2} \mathrm{O}_{2}$ (Synth) and incubated at $37^{\circ} \mathrm{C}$ for $30 \mathrm{~min}$. For MPO quantification, $25 \mu \mathrm{L}$ of supernatant were added to $25 \mu \mathrm{L}$ of $1.6 \mathrm{mM}$ 3,3,5,5'-Tetramethylbenzidine (TMB, Sigma-Aldrich, St. Louis, MO, USA) in dimethyl sulfoxide (DMSO, Sigma-Aldrich, St. Louis, MO, USA). After the addition of $100 \mu \mathrm{L} 0.5 \mathrm{mM} \mathrm{H}_{2} \mathrm{O}_{2}$, the solution was incubated at $37^{\circ} \mathrm{C}$ for $5 \mathrm{~min}$. Fifty microliters of $1 \mathrm{M} \mathrm{H}_{2} \mathrm{SO}_{4}$ were added to stop both reactions. Absorbance was measured at $492 \mathrm{~nm}$ (EPO) and $450 \mathrm{~nm}$ (MPO) on a microplate spectrophotometer (Bio-Rad 450 model, Bio-Rad Laboratories, Hercules, CA, USA). Results were expressed as MPO or EPO arbitrary units (based on absorbance)/100 mg of tissue.

\subsection{Intestinal Secretory $\operatorname{Ig} A(\operatorname{sg} A)$}

An enzyme-linked immunosorbent assay (ELISA) was used to measure the sIgA levels in the small intestine, as described by Martins et al. [57]. To this end, the bowel contents were removed, weighed, and flushed out (PBS 0.1 M (pH 7.2) supplemented with aprotinin (1 $\mu \mathrm{M}$, Sigma-Aldrich, St. Louis, MO, USA), leupeptin ( $25 \mu \mathrm{M}$, SigmaAldrich, St. Louis, MO, USA), pepstatin (1 $\mu \mathrm{M}$, Sigma-Aldrich, St. Louis, MO, USA), and phenylmethanesulfonyl fluoride (PMSF, $1 \mathrm{mM}$, Sigma-Aldrich, St. Louis, MO, USA)). Samples were centrifuged (2000 rpm for $30 \mathrm{~min}$ at $4{ }^{\circ} \mathrm{C}$ ), and the supernatant was collected to find the immunoglobulin dosage. Microtiter plates (Nunc-Immuno Plates, MaxiSorp) were coated with goat anti-mouse IgA antibody (M-8769, Sigma-Aldrich, St. Louis, MO, USA) in coat buffer ( $\left.1 \mathrm{M} \mathrm{Na}_{2} \mathrm{CO}_{3} ; 0.1 \mathrm{M} \mathrm{NaHCO} 3 ; \mathrm{pH} 9.6\right)$ for $18 \mathrm{~h}$ at $4{ }^{\circ} \mathrm{C}$, washed (0.1 M PBS + 0.05\% Tween 20), and blocked (1\% albumin in PBS-Tween 20). Afterward, pre-diluted intestinal fluids (1:1000-0.1 M PBS-Tween 20) were incubated for $1 \mathrm{~h}$. The plates were then washed, and a biotin-conjugated anti-mouse IgA antibody (dil. 1:1000, A4789, Sigma-Aldrich, St. Louis, MO, USA) was added and incubated for $1 \mathrm{~h}$. Finally, $100 \mu \mathrm{L} /$ well of OPD $(1 \mathrm{mg} / \mathrm{mL})$ and $0.04 \% \mathrm{H}_{2} \mathrm{O}_{2}$ substrates were added and set for $10 \mathrm{~min}$. The reaction was stopped with $20 \mu \mathrm{L}$ /well of $1 \mathrm{M} \mathrm{H}_{2} \mathrm{SO}_{4}$ (Sigma-Aldrich, St. Louis, MO, USA). The absorbance was determined at $492 \mathrm{~nm}$ using a microplate reader (Bio-Rad model 450, Bio-Rad Laboratories, Hercules, CA, USA). The immunoglobulin concentration was 
determined using a purified mouse IgA standard (M-8769, Sigma-Aldrich, St. Louis, MO, USA). The concentration of sIgA was expressed in $\mu \mathrm{g} / \mathrm{mL}$ of intestinal content.

\subsection{Transmission Electron Microscopy (MET)}

An ileum section $(1.5 \mathrm{~cm})$ was fixed in modified Karnovsky solution [ $(2.5 \%$ glutaraldehyde, paraformaldehyde $2.5 \%$, in PBS $0.1 \mathrm{M}(\mathrm{pH}=7.2)]$ at $4{ }^{\circ} \mathrm{C}$ for $24 \mathrm{~h}$. Then the solution was removed and substituted with PBS $0.1 \mathrm{M}(\mathrm{pH}=7.2)$, the samples were post-fixed/block stained in $2 \%$ osmium tetroxide (OsO4) in PBS $0.1 \mathrm{M}$ for $2 \mathrm{~h}$ at room temperature, and $2 \%$ uranyl acetate in $\mathrm{H}_{2} \mathrm{O}$ at $4{ }^{\circ} \mathrm{C}$ was added and incubated overnight. The fixed tissues were desiderated with ethanol (PA, LabSynth, São Paulo, Brazil) and acetone (PA, LabSynth, São Paulo, Brazil) and embedded in epoxy resin. Semi-thin cuts were done (approximately $300 \mathrm{~nm}$ ) using a glass razor. The specific sections were chosen in these samples, and ultrathin cuts (approximately $60 \mathrm{~nm}$ ) using diamond razors were performed. These sections were placed on a $\mathrm{Cu}$ screen (300 mesh) contrasted with lead citrate stains. The images were examined under transmission electron microscopy (TEM; Tecnai G2-1, SpiritBiotwin EIF, $120 \mathrm{kV})$.

\subsection{RNA Extraction and Real-Time RT-qPCR of Ileum Section}

Total RNA was extracted from $30 \mathrm{mg}$ of ileum tissue, previously stored in $500 \mu \mathrm{L}$ of RNA later solution (Invitrogen, Carlsbad, CA, USA) to preserve the samples, using TRIzol reagent (Invitrogen, Carlsbad, CA, USA) in compliance with the manufacturer's guidelines. The RNA concentrations were determined spectrophotometrically using a NanoDrop 2000 (Thermo Scientific, Waltham, MA, USA), considering absorbance ratios of $280 / 260$ and $260 / 230 \mathrm{~nm}$. The quality of RNA samples was evaluated in agarose electrophoresis gel (1.5\%). The extracted RNA was treated for $15 \mathrm{~min}$ at room temperature with DNAse I (Invitrogen, Carlsbad, CA, USA). After that, the enzyme was deactivated (10 min $65^{\circ} \mathrm{C}$ with $25 \mathrm{mM}$ EDTA). One microgram of total RNA was reverse transcribed using MultiScrib reverse transcriptase (Thermo Fisher, Waltham, MA, USA) in compliance with its guidelines, forming complementary deoxyribonucleic acid (cDNA) using the following parameters: $25^{\circ} \mathrm{C}$ for $10 \mathrm{~min}, 37^{\circ} \mathrm{C}$ for $120 \mathrm{~min}, 85^{\circ} \mathrm{C}$ for $5 \mathrm{~min}$.

Quantitative reverse transcription PCR (RT-qPCR) was performed using Applied Biosystems Power SYBR Green PCR master mix (Thermo Fisher, Waltham, MA, USA) and gene-specific primers for Tnf, Il1b, Il6, Il12, Il10, Muc2, claudin 1, 2, and 5, junctional adhesion molecule 1 (F11r), zonulin, occludin, Tlr2, Tlr4, nitric oxide synthase 2 (Nos2), and Myd88 (Table 1). Transcripts were all normalized using Actb and Gapdh [58] housekeeping genes. The experimental approach was optimized by adjusting the primers' concentrations $(5,10$, and $15 \mathrm{pmol})$ to test for optimal specificity and efficiency. The purity of PCR products was verified by melting curves and gel electrophoresis. The PCR cycle parameters were as follows: initial denaturation at $95^{\circ} \mathrm{C}$ for $10 \mathrm{~min}, 95^{\circ} \mathrm{C}$ for $15 \mathrm{~s}$, annealing/extension at $60^{\circ} \mathrm{C}$ for $1 \mathrm{~min}, 40$ cycles, followed by a dissociation stage for recording the melting curve. Results were shown graphically as fold changes in gene expression, using the means and standard deviations of target gene expression by Hellemans et al. [59]. Data were analyzed according to the relative expression using the $2^{-\Delta \Delta C T}$ method. Data are representative of two independent experiments.

\subsection{Statistical Analysis}

The Shapiro-Wilk test assessed data normality. Normal data (body weight loss, small intestine length, sIgA levels, MPO activity, leukocyte count, intestinal permeability, bacterial translocation, villus height to crypt depth ratio, histological score, number of goblet cells, RT-qPCR) were evaluated by analysis of variance (ANOVA) followed by the Bonferroni post hoc test (parametric distribution). Non-normal data (non-parametric distribution) (food and milk intake, EPO activity) were evaluated by the Kruskal-Wallis test followed by Dunn's post hoc test. A Mann-Whitney test was performed to compare 
food and milk intake before and after mucositis induction. All data were analyzed using GraphPad Prism 7.0 software, and $p<0.05$ was considered statistically significant.

Table 1. Primers used in qPCR.

\begin{tabular}{llll}
\hline Gene & Foward Primer & Reverse Primer & Reference \\
\hline Actb & GCTGAGAGGGAAATCGTGCGTG & CCAGGGAGGAAGAGGATGCGG & {$[60]$} \\
\hline Gapdh & TCACCACCATGGAGAAGGC & GCTAAGCAGTTGGTGGTGCA & {$[58]$} \\
\hline Il6 & GAGGATACCACTCCCAACAGACC & AAGTGCATCATCGTTGTTCATACA & {$[58]$} \\
\hline Il10 & GGTTGCCAAGCCTTATCGGA & ACCTGCTCCACTGCCTTGCT & {$[58]$} \\
\hline Il12p40 & GGAAGCACGGCAGCAGAATA & AACTTGAGGGAGAAGTAGGAATGG & {$[58]$} \\
\hline Tnf & ACGTGGAACTGGCAGAAGAG & CTCCTCCACTTGGTGGTTTG & {$[61]$} \\
\hline Il1b & CTCCATGAGCTTTGTACAAGG & TGCTGATGTACCAGTTGGGG & {$[61]$} \\
\hline Muc2 & GATGGCACCTACCTCGTTGT & GTCCTGGCACTTGTTGGAAT & {$[60]$} \\
\hline Myd88 & ATCGCTGTTCTTGAACCCTCG & CTCACGGTCTAACAAGGCCAG & {$[62]$} \\
\hline Tlr2 & ACAATAGAGGGAGACGCCTTT & AGTGTCTGGTAAGGATTTCCCAT & {$[62]$} \\
\hline Tlr4 & ATGGCATGGCTTACACCACC & GAGGCCATTTTTGTCTCCACA & {$[62]$} \\
\hline Nos2 & CAGCTGGGCTGTACAAACCTT & CATTGGAAGTGAAGCGTTTCG & {$[58]$} \\
\hline Cldn1 & TCCTTGCTGAATCTGAACA & AGCCATCCACATCTTCTG & {$[60]$} \\
\hline Cldn2 & GTCATCGCCCATCAGAAGAT & ACTGTTGGACAGGGAACCAG & {$[60]$} \\
\hline Cldn5 & GCTCTCAGAGTCCGTTGACC & CTGCCCTTTCAGGTTAGCAG & {$[60]$} \\
\hline Occludin & ACTCCTCCAATGGACAAGTG & CCCCACCTGTCGTGTAGTCT & {$[60]$} \\
\hline Zonulin & CCACCTCTGTCCAGCTCTTC & CACCGGAGTGATGGTTTTCT & {$[60]$} \\
\hline F11r & CACCTTCTCATCCAGTGGCATC & CTCCACAGCATCCATGTGTGC & {$[60]$} \\
\hline
\end{tabular}

\section{Results}

\subsection{Eukaryotic Cells Can Express Hsp65 Protein}

Enzymatic digestion of the new construction, pExu:hsp65, confirmed the successful cloning of the Hsp65 sequence in the pExu vector. The immunohistochemical images revealed a precise localization of Hsp protein expression in the cytoplasm of transfected eukaryotic cells with the pExu:hsp65 plasmid (Figure 1). Thus, the confocal assay confirmed plasmid pExu:hsp65 functionality. The construction of recombinant strain L. delbrueckii CIDCA 133 (pExu:hsp65) was confirmed by plating on an MRS/erythromycin plate and plasmid extraction.

\section{2. $r$ CIDCA 133:Hsp65 Prevented Small Intestine Shortening and Decrease in Weight Loss}

Intestinal shortening was observed in inflamed animals, the MUC group $(\sim 46 \pm 1.80 \mathrm{~cm})$, as expected. Statistical difference was observed $(p<0.001)$ when the MUC group was compared with non-treated animals (CTL group) $(\sim 54 \pm 1.34 \mathrm{~cm})$. It was possible to observe that treatments with either recombinant strains (rCIDCA 133 and rCIDCA 133:Hsp65) were able to attenuate the small intestine shortening $(\sim 50 \pm 0.93$ and $\sim 52.5 \pm 1.34 \mathrm{~cm}$, respectively) $(p<0.001)$. However, intestinal shortening prevention was significantly stronger in animals that received the rCIDCA 133:Hsp65 strain, reaching similar levels to the negative control group (Figure 2A).

The time course of the mice's weight was another parameter that was evaluated. The bodyweight loss of mice of the rCIDCA 133:Hsp65 group was significantly lower 
(approximately $4 \%$ ) than those in the MUC group (about 5.5\%) $(p<0.01)$ (Figure 2B). No mortality was observed during the experiment.

Total milk and food intake were similar in all analyzed groups before the induction of mucositis ( $4 \mathrm{~mL}$ and $3 \mathrm{~g} /$ day / animal, respectively). There were no significant statistical differences between the experimental groups. After induction of intestinal mucositis, the MUC group showed a reduction in food and milk intake $(1.063 \pm 0.76 \mathrm{~g}$ and $1.208 \pm 0.07 \mathrm{~mL})$ when compared with the negative control $(2.969 \pm 0.25 \mathrm{~g}$ and $3.531 \pm 0.77 \mathrm{~mL})(p<0.01)$. Nevertheless, the administration of rCIDCA $133(1.469 \pm 0.70 \mathrm{~g}$ and $2.094 \pm 0.87 \mathrm{~mL})$ and rCIDCA 133:Hsp65 $(1.531 \pm 0.55 \mathrm{~g}$ and $2.750 \pm 0.90 \mathrm{~mL})$ treatments was not able to modify these parameters (Figure 2C,D).

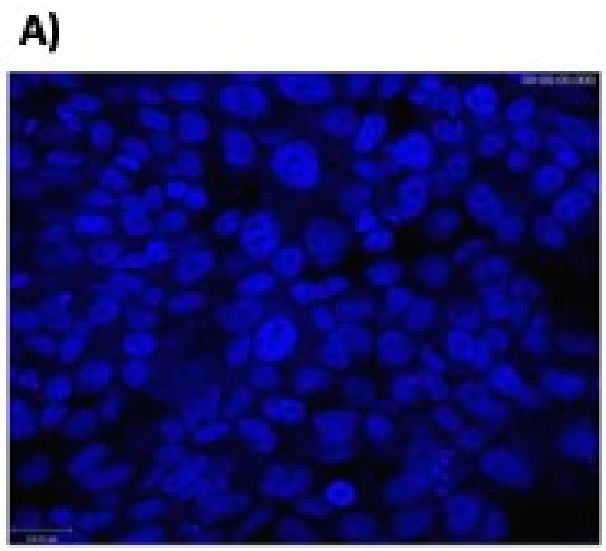

\section{C)}

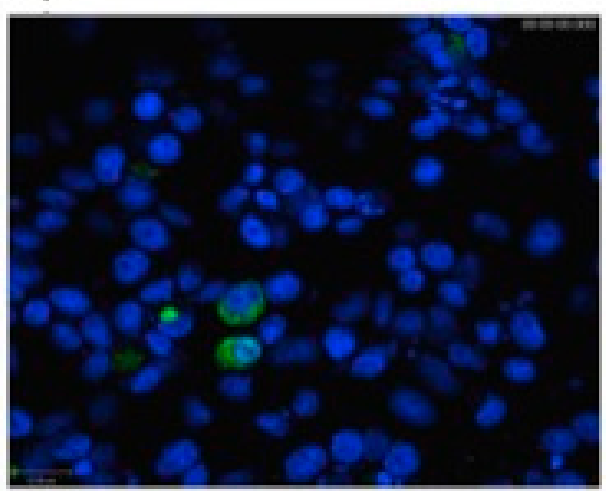

B)

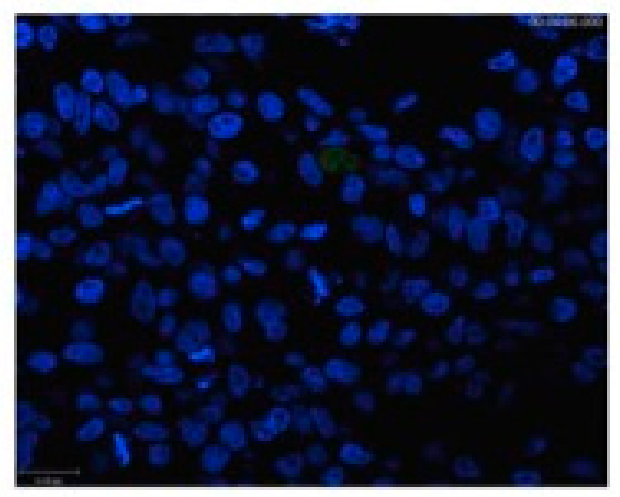

D)

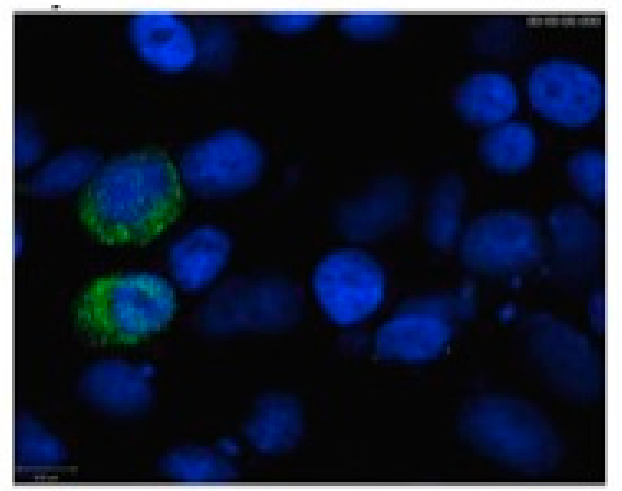

Figure 1. Hsp65 expression in transfected eukaryotic cells. Confocal microscopy: (A) negative control: non-transfected Chinese Hamster Ovarian cell line (CHO) cells; (B) negative control: non-transfected eukaryotic cells labeled with primary (Mab anti-Hsp65) and secondary (goat anti-mouse IgG $(\mathrm{H}+\mathrm{L})$ ) antibodies labeled with Alexa 488. (C,D) CHO cells labeled with primary (Mb_HSP65) and secondary (goat anti-mouse $\operatorname{IgG}(\mathrm{H}+\mathrm{L})$ ) antibodies. In green, the Hsp65 protein is expressed in the cytoplasm of eukaryotic cells. 2D images (A-D) were acquired in both depths (z-stack) using a Zeiss LSM 510 META inverted confocal laser 1358 scanning microscope with $40 \times$ or $60 \times$ objective.

\section{3. rCIDCA 133:Hsp65 Treatment Reduced Ileum Inflammatory Infiltrate and Increased sIgA Levels}

The activity of myeloperoxidase (MPO) and eosinophil peroxidase (EPO) was measured in ileum cell lysates to verify whether treatment with rCIDCA 133:Hsp65 could reduce the infiltration of inflammatory cells, like neutrophils and eosinophils, in the intestinal mucosal layer. As exposed in Figure 3A,B, the MUC group (positive control) significantly presented an increase in MPO and EPO enzymes activities, thus showing an increase in neutrophil and eosinophil recruitment $(2.453 \pm 0.17 \mathrm{U} / \mathrm{mg}$ for MPO; $1.561 \pm 0.07 \mathrm{U} / \mathrm{mg}$ for EPO) $(p<0.001)$ due to the inflammatory processes. Animals treated with rCIDCA 
133:Hsp65 showed a reduction in the activity of both enzymes $(1.623 \pm 0.22 \mathrm{U} / \mathrm{mg}$ for MPO, $(p<0.001) ; 0.434 \pm 0.04 \mathrm{U} / \mathrm{mg}$ for $\mathrm{EPO}, p<0.01)$.

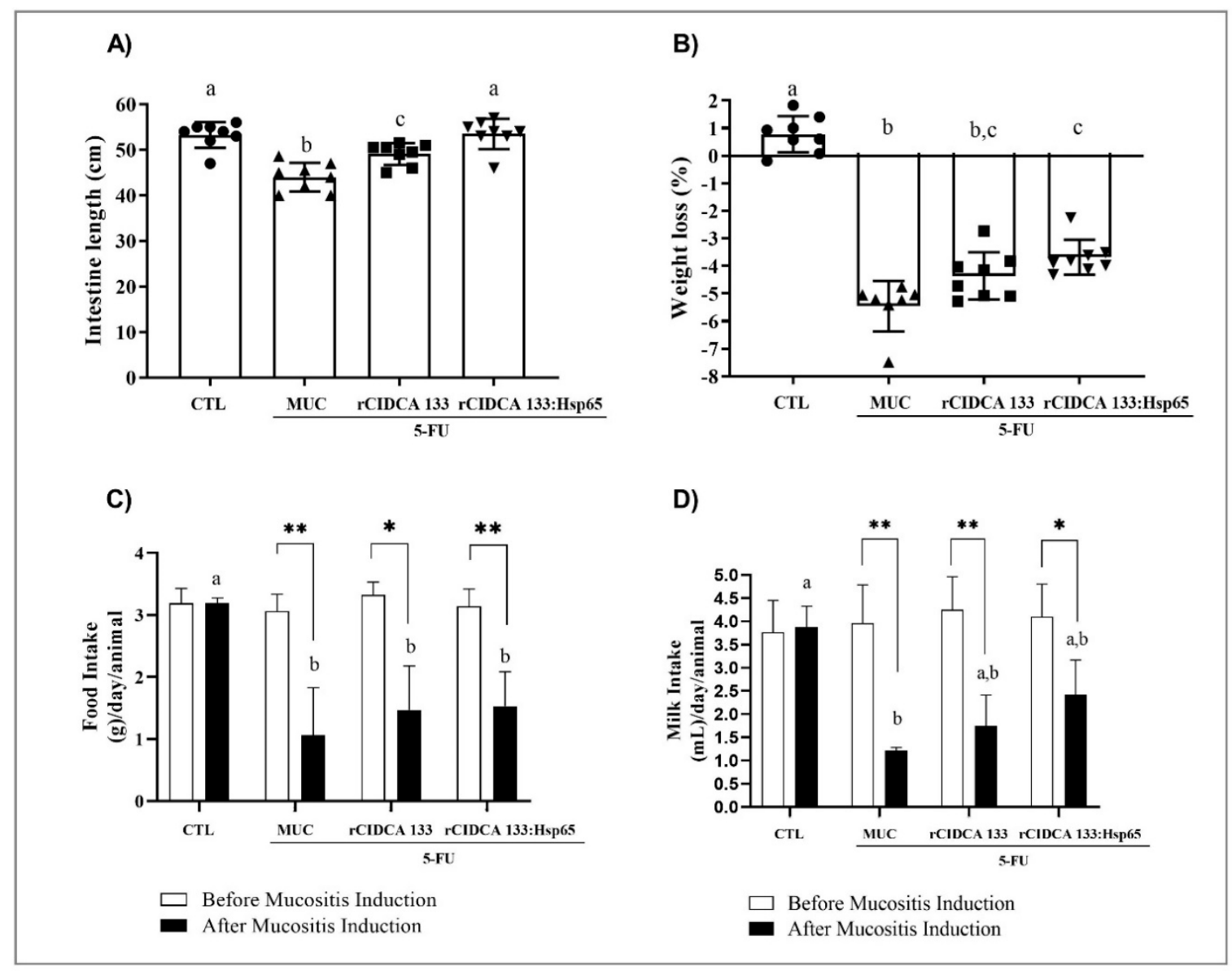

Figure 2. Small intestine length, bodyweight, food and milk intake analysis: (A) intestine length, (B) bodyweight variation (C) food intake, and (D) milk intake. (A,B) ANOVA followed by the Bonferroni post hoc test and (C,D) Kruskal-Wallis test followed by Dunn's post hoc test. Different letters $(a, b$, and $c)$ indicate statistically significant differences between groups $(p<0.05)$. The symbols $\left(^{*}\right)\left(^{* *}\right)$ show a statistically significant difference $(p<0.05)(p<0.01)$, respectively, between rCIDCA 133, MUC (positive control), and rCIDCA 133:Hsp65 groups before and after mucositis induction by an unpaired Student's $t$-test (C,D). Geometric symbols show to the number of animals evaluated in each experimental group. $\bullet$ refers to the animals of CTL group, $\boldsymbol{\Delta}$ refers to the animals of MUC group, $\mathbf{\square}$ refers to the animals of rCIDCA 133 group and $\mathbf{\nabla}$ refers to the animals of rCIDCA 133:Hsp65 group.

A significant reduction in the number of blood leukocytes/ $\mu \mathrm{L}$ was observed after 5-FU administration in the MUC group $(0.775 \pm 0.11$ cells $\times 103 / \mu \mathrm{L})$ when compared to the negative control (CTL) $(3.638 \pm 0.46$ cells $\times 103 / \mu \mathrm{L})(p<0.001)$, as expected. However, the reduction of total leukocyte blood rate induced by chemotherapy was minimized after treatment with either rCIDCA $133(1.440 \pm 0.30$ cells $\times 103 / \mu \mathrm{L})(p<0.01)$ or rCIDCA 133:Hsp65 $(1.814 \pm 0.60$ cells $\times 103 / \mu \mathrm{L})(p<0.001)$. No statistical difference was observed between treatments with both recombinant strains (Figure $3 \mathrm{C}$ ).

Levels of secretory $\operatorname{Ig} \mathrm{A}(\operatorname{sg} \mathrm{A})$ were also investigated. The results showed that the sIgA levels in the intestinal fluid of the MUC group were significantly increased $(3517.2 \pm 131.8 \mu \mathrm{g} / \mathrm{mL})$, and a statistical difference was observed when this group was compared with the negative control $(2199.4 \pm 330.4 \mu \mathrm{g} / \mathrm{mL})(p<0.001)$. The treatment with rCIDCA 133 showed significantly reduced levels of $\operatorname{sIgA}(2905.8 \pm 242.6 \mu \mathrm{g} / \mathrm{mL})$; $(p<0.001)$ in the intestinal fluid of the animals that had received chemotherapy. However, mice treated with rCIDCA 133:Hsp65 were able to increase immunoglobulin levels $(3988.2 \pm 100.5 \mu \mathrm{g} / \mathrm{mL})$ significantly, higher than in the MUC group $(p<0.01)$ (Figure 3D). 


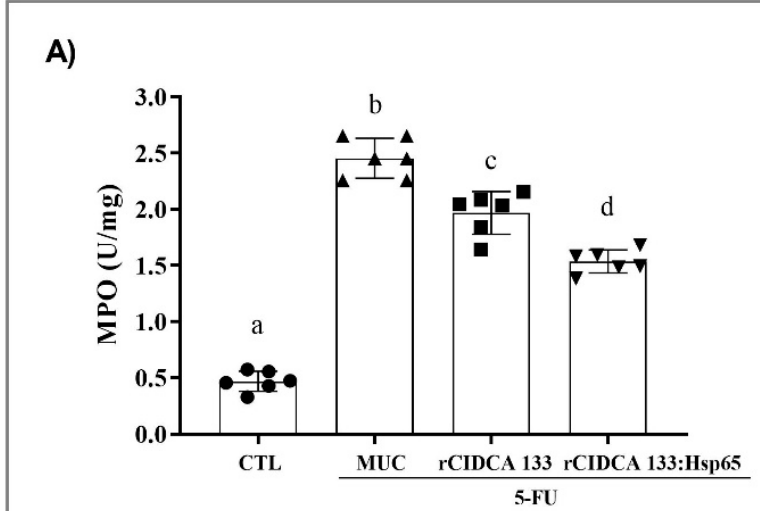

C)

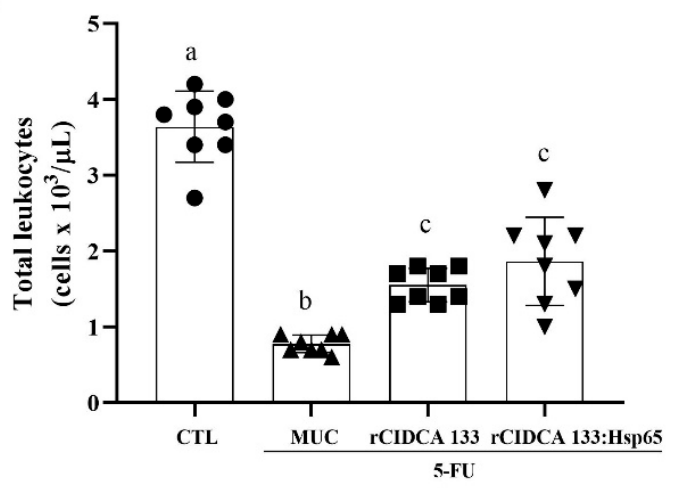

B)

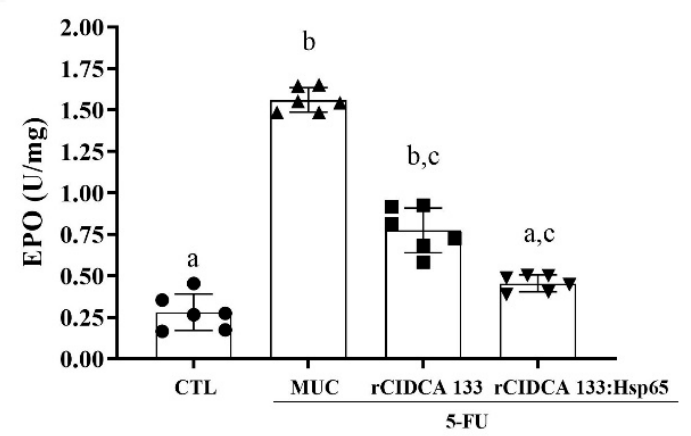

D)

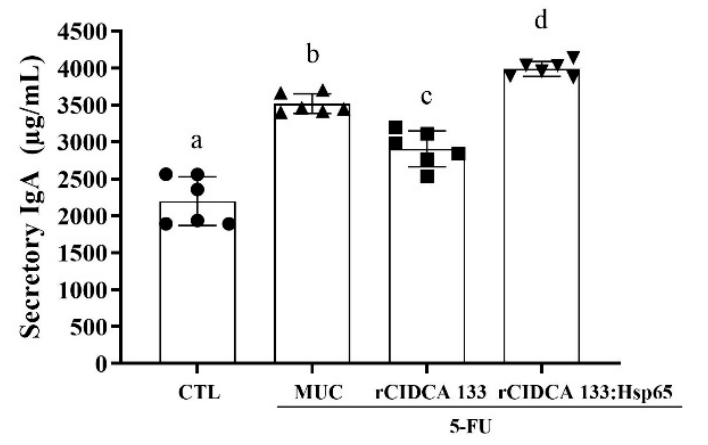

Figure 3. Effect of rCIDCA 133:Hsp65 on inflammatory parameters and epithelial barrier of animals inflamed with 5fluorouracil (5-FU): (A) Intestinal Myeloperoxidase (MPO) and (B) Eosinophil Peroxidase (EPO) activity, (C) intestinal permeability (\%ID/g of 99mTc-DTPA), and (D) levels of Intestinal Secretory IgA (sIgA) $(\mu \mathrm{g} / \mathrm{mL}$ ). Mice received intraperitoneal 5-FU (300 mg/kg) (MUC, rCIDCA 133, and rCIDCA 133:Hsp65 groups) or $0.9 \%$ saline solution (CTL group) and were treated with non-fermented milk or recombinant L. delbrueckii CIDCA 133-fermented milk ( $n=6$ animals per group). Different letters indicate statistically significant differences $(p<0.05)$ by ANOVA followed by the Bonferroni post hoc test $(\mathbf{A}, \mathbf{C}, \mathbf{D})$ and Kruskal-Wallis test followed by Dunn's post hoc test (B). Geometric symbols show to the number of animals evaluated in each experimental group. $\bullet$ refers to the animals of CTL group, $\mathbf{\Delta}$ refers to the animals of MUC group, $\boldsymbol{\square}$ refers to the animals of rCIDCA 133 group and $\mathbf{v}$ refers to the animals of rCIDCA 133:Hsp65 group.

\subsection{Reduction in Intestinal Permeability after Treatment with rCIDCA 133:Hsp65}

Alteration of mucosal permeability is another side effect of 5-FU treatment. The intestinal permeability was evaluated by measuring radioactivity diffusion in the blood following oral administration of $99 \mathrm{mTc}-\mathrm{DTPA} 72 \mathrm{~h}$ after the 5-FU injection. Intestinal permeability was significantly increased in the MUC group $(0.258 \pm 0.024 \% \mathrm{ID} / \mathrm{g})$. On the other hand, the CTL group showed lower permeability $(0.0187 \pm 0.008 \% \mathrm{ID} / \mathrm{g})(p<0.001)$, as expected. Interestingly, the oral administration with rCIDCA 133:Hsp65 promoted a significant reduction in this parameter $(0.0363 \pm 0.015 \% \mathrm{ID} / \mathrm{g})$, reaching similar levels to the negative control (Figure $4 \mathrm{~A})$. The same effect was observed in mice treated with the rCIDCA 133 strain. However, the levels of radioactivity were higher than in the rCIDCA 133:Hsp65 group $(0.0663 \pm 0.026 \% \mathrm{ID} / \mathrm{g}$ and $0.0363 \pm 0.015 \% \mathrm{ID} / \mathrm{g}$, respectively). 
A)

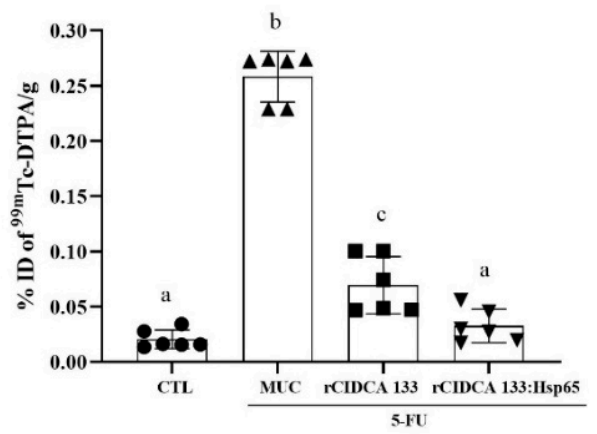

C)

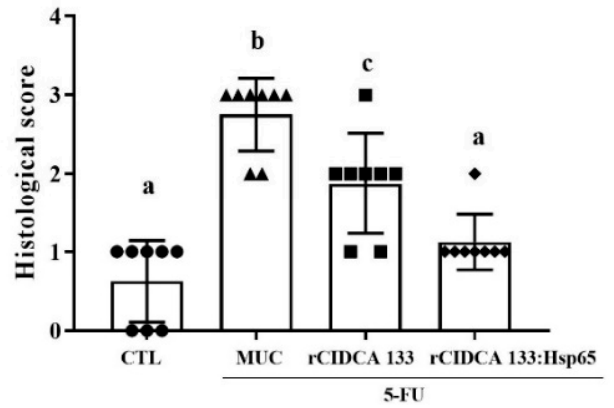

E)

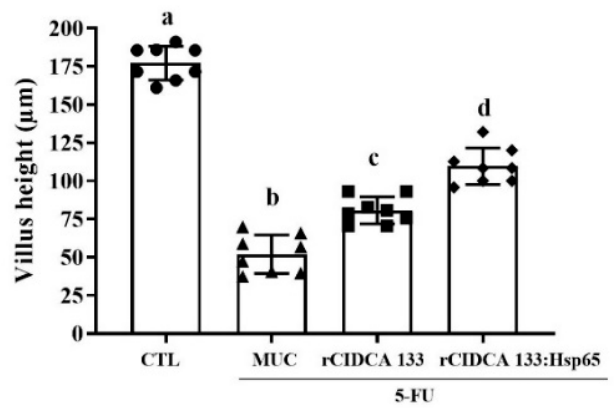

B)

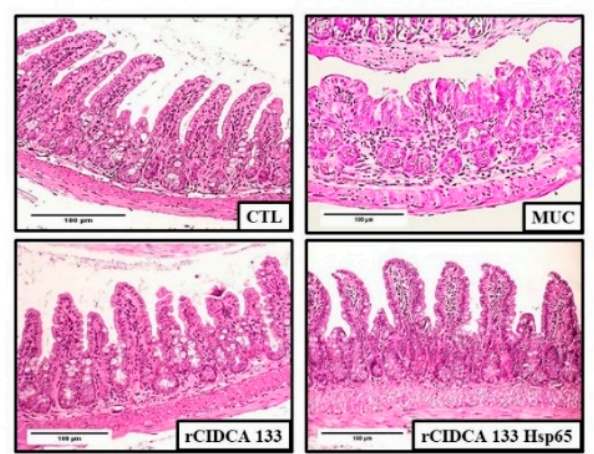

D)

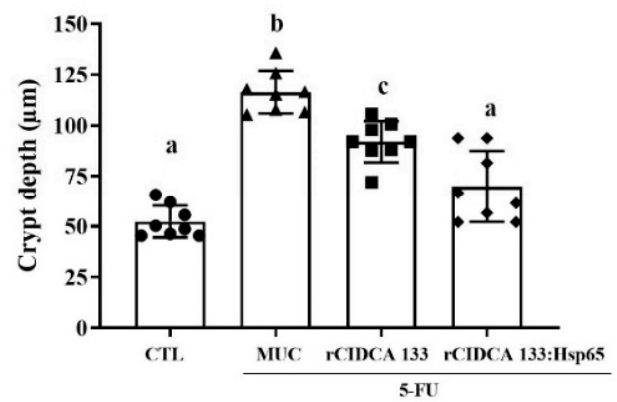

F)

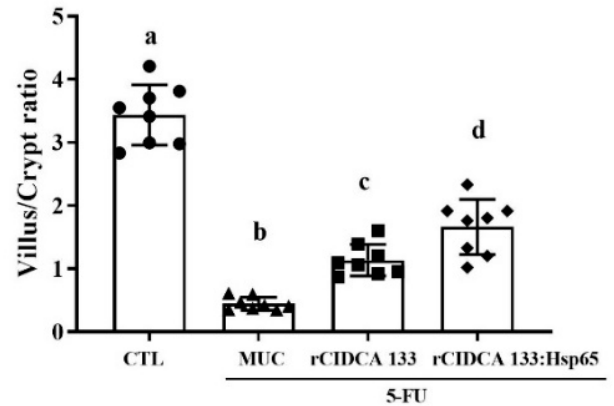

Figure 4. Histopathological and morphometric analysis, intestinal permeability, and evaluation of the relative gene expression of tight junction proteins: (A) intestinal permeability (\%ID/g of 99mTc-DTPA), (B) mucosal histopathology, (C) histopathological scores of the ileum of animals (objective: $\times 20$, scale $100 \mu \mathrm{m}$ ), (D) morphometrical analysis of crypt depth, (E) villus height, (F) villus height to crypt depth ratio. Mice received intraperitoneal 5-FU (300 mg/kg) (MUC, rCIDCA 133, and rCIDCA 133:Hsp65 groups) or saline solution (CTL group). They were treated with non-fermented milk supplemented with erythromycin 2.5\% (CTL and MUC) or recombinant L. delbrueckii CIDCA 133 (rCIDCA133 and rCIDCA133:Hsp65)-fermented milk supplemented with erythromycin 2.5\% ( $n=8$ animals per group). Different letters $(\mathrm{a}-\mathrm{d})$ indicate statistically significant differences $(p<0.05)$ by ANOVA followed by the Bonferroni post hoc test. Geometric symbols show to the number of animals evaluated in each experimental group. $\bullet$ refers to the animals of CTL group, $\Delta$ refers to the animals of MUC group, $\mathbf{\square}$ refers to the animals of rCIDCA 133 group and $\boldsymbol{\nabla}$ refers to the animals of rCIDCA 133:Hsp65 group. 
3.5. rCIDCA 133:Hsp65 Reduced Both Mucosal Damage and Degeneration of Goblet Cells in 5-FU-Induced Intestinal Mucositis

Mice inflamed by 5-FU (MUC group) demonstrated significant alteration in mucosal integrity, such as villus shortening, increased crypt depth, and intense inflammatory cell infiltrate in villi and in lamina propria and submucosa, with ulceration, edema, and vacuolization. Figure 4B shows these findings, which were also confirmed by the scoring system (score 3) [55] (Figure 4C). The rCIDCA 133:Hsp65 and rCIDCA 133 treatments were able to alleviate 5-FU-induced intestinal mucosal damage. The histology assays showed a decreased inflammatory infiltrate, and in the crypt depth and villus height, it was significantly restored (Figure 4D,E). Consequently, the villus height to crypt depth ratio was increased, and histological scores were significantly decreased (1 and 2, respectively) (Figure $4 \mathrm{C}, \mathrm{F}$ ), revealing that both recombinant strains can improve the mucosal preservation in the inflamed mice. However, the treatment with the rCIDCA 133:Hsp65 strain was able to potentiate the decrease in inflammation. A significant decline in goblet cells $(12.07 \pm 5.16$ cell / field) was observed in the MUC group, as expected. Both recombinant strains studied were able to improve the loss of goblet cell numbers. This protection was significantly higher $(36.07 \pm 6.64$ cell $/$ field $)$ in mice orally treated with rCIDCA 133:Hsp65 than in those which received the rCIDCA 133 strain $(26.33 \pm 1.98$ cell/field $)(p<0.01)$ (Figure 5A,B). On the other hand, the down-regulation of the gene expression of Muc2 mucin $(0.17 \pm 0.05)$ after 5 -FU administration (MUC group) was observed, with this expression being significantly different from the control groups (Muc2: CTL $=1.10 \pm 0.14$; rCIDCA $133=0.46 \pm 0.02)(p<0.05)$. Animals treated with CIDCA 133:Hsp65 showed an up-regulated expression of the Muc2 gene $(0.76 \pm 0.17)(p<0.05$, Figure $5 C)$.

\subsection{Tight Junctions Exhibit Up-Regulation after Oral Administration with Recombinant Strains}

The results of the gene expression of tight junction proteins, such as Cldn1 $(0.15 \pm 0.02)$, Cldn2 (0.06 \pm 0.07$),$ Cldn5 (0.26 \pm 0.09$)$, occludin (0.14 \pm 0.06$)$, zonulin (0.35 \pm 0.07$)$, and F11r $(0.25 \pm 0.14)$, showed an important gene suppression in ileum tissue in the MUC group, as expected. Both recombinant strains studied, rCIDCA 133 and rCIDCA 133:Hsp65, were able to up-regulate the gene expression of Cldn1 $(0.68 \pm 0.15 ; 0.36 \pm 0.10)$ Cldn2 (0.32 \pm 0.11 ; $0.67 \pm 0.14)$, occludin $(0.40 \pm 0.07 ; 0.43 \pm 0.13)$, zonulin $(0.65 \pm 0.16 ; 0.70 \pm 0.09)$, and F11r $(0.71 \pm 0.12 ; 1.07 \pm 0.08)(p<005)$. Animal treatment with rCIDCA 133:Hsp65 strains showed up-regulation in the gene expression of Cldn1 and 2, and F11r (Figure 6A-F).

The ultrastructural examination of ileum mucosa displayed a reduction in the number of microvilli and a greater distance between them. It was possible to observe a higher vacuole number, deficiency of occlusion junctions, and ample open space in adherent junctions and desmosomes compared with control mice. The ultrastructural analyses for either recombinant treatment corroborate the findings of relative gene expression showing, at least in part, that these parameters were ameliorated in animals that received both recombinant strains (Figure 6G).

3.7. rCIDCA 133:Hsp65 Reduces Gene Expression of Pro-Inflammatory Molecules and Upregulates the IL10 Expression in Ileum of Inflamed Animals

The qPCR results reveal that the relative mRNA expression of $\operatorname{Tnf}(7.28 \pm 0.42)$, Il1b (2.3 \pm 0.49$)$, Il6 (1.47 \pm 0.34$)$, and Il12 (3.01 \pm 0.52$)$ were up-regulated in animals from the MUC group, contrary to those exhibited in the CTL group: Tnf $(1.0 \pm 0.74)(p<0.0001)$, $\mathrm{Il1b}(1.0 \pm 0.14)(p<0.0001), \mathrm{Il} 6(1.0 \pm 0.10)(p<0.05), \mathrm{Il} 12(1.0 \pm 0.17)(p<0.0001)$. Oral treatment with either rCIDCA 133 and rCIDCA 133:Hsp65 was able to suppress $\operatorname{Tnf}(1.94 \pm 0.86 ; 1.48 \pm 0.13$, respectively) $(p<0.0001)$, Il1b $(1.04 \pm 0.26 ; 0.40 \pm 0.11$, respectively) $(p<0.0001)$, Il6 (1.05 $\pm 0.18 ; 0.22 \pm 0.07$, respectively) $(p<0.05 ; p<0.0001)$, and also Il12 (1.07 $\pm 0.27 ; 1.56 \pm 0.75$, respectively) $(p<0.0001 ; p<0.001)$. It was observed that levels of the anti-inflammatory Il10 cytokine were reduced $(0.08 \pm 0.03)(p<0.05)$ after the administration of 5-FU (MUC group) in relation to the CTL group $(1.0 \pm 0.27)$ $(p<0.0001)$. Both recombinant strains studied, rCIDCA 133 and rCIDCA 133:Hsp65, 
were able to up-regulate Il10 $(0.71 \pm 0.16 ; 0.77 \pm 0.20$, respectively $)(p<0.001)$ expression (Figure 7A-E).

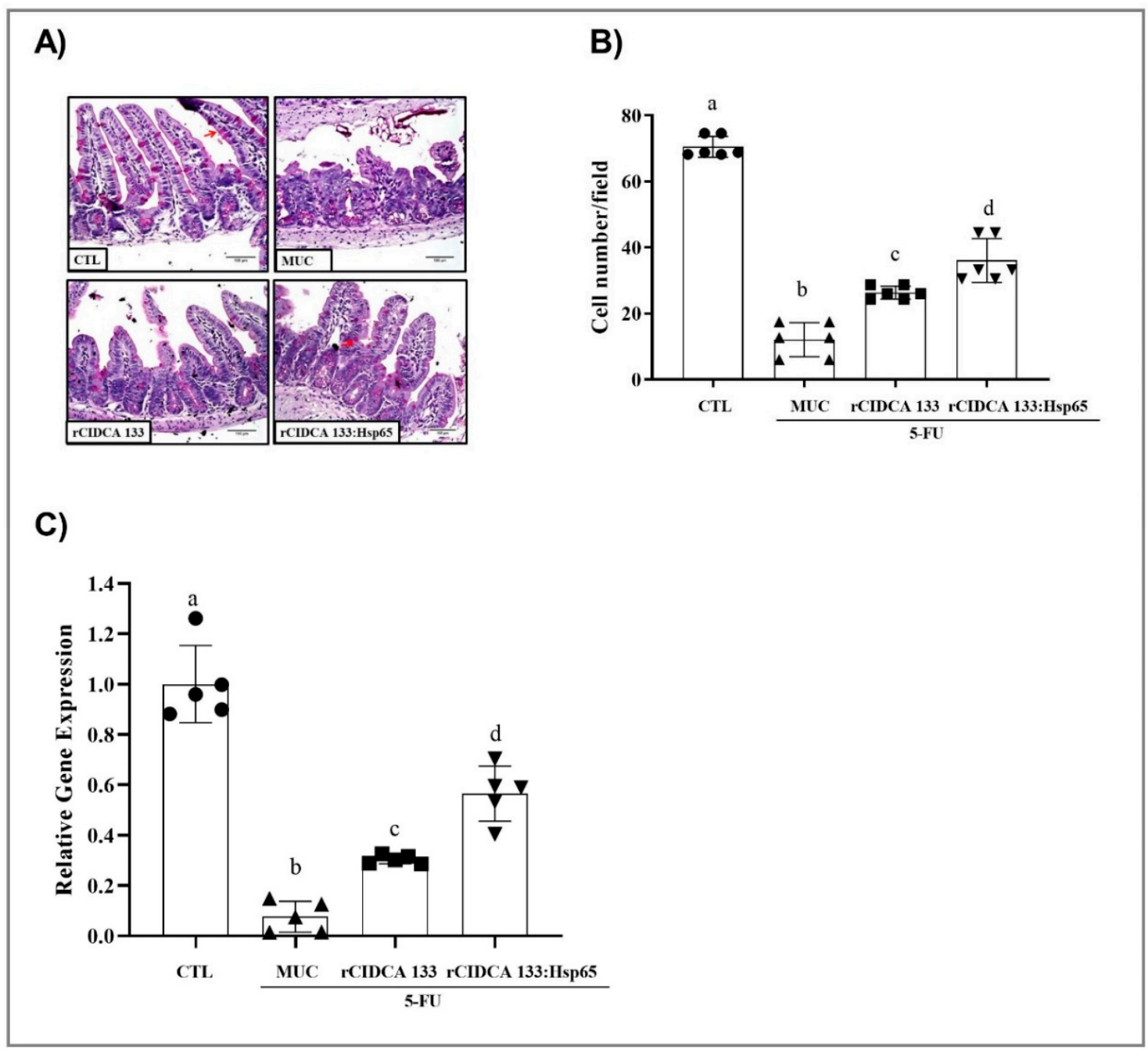

Figure 5. Assessment of goblet cell integrity and evaluation of the relative gene expression of Muc2 mucin: (A) representative photomicrographs from ileum section stained with Periodic Acid-Schiff (PAS), the arrows show the goblet cells (objective: $\times 20$, scale $100 \mu \mathrm{m}),($ B $)$ number of goblet cells/field obtained for experimental groups, and (C) level of relative mRNA expression of Muc2 mucin. Mice received intraperitoneal 5-FU (300 mg/kg) (MUC, rCIDCA 133, and rCIDCA 133:Hsp65 groups) or saline solution (CTL group). They were treated with non-fermented milk supplemented with erythromycin 2,5\% (CTL and MUC) or recombinant L. delbrueckii CIDCA 133 (rCIDCA133 and rCIDCA133:Hsp65)-fermented milk supplemented with erythromycin 2,5\% ( $n=6$ animals per group). Different letters (a-d) indicate statistically significant differences $(p<0.05)$ by ANOVA followed by the Bonferroni post hoc test $(\mathbf{B}, \mathbf{C})$. Geometric symbols show to the number of animals evaluated in each experimental group. $\bullet$ refers to the animals of CTL group, $\mathbf{\Delta}$ refers to the animals of MUC group, refers to the animals of rCIDCA 133 group and $\boldsymbol{\nabla}$ refers to the animals of rCIDCA 133:Hsp65 group. 
A)

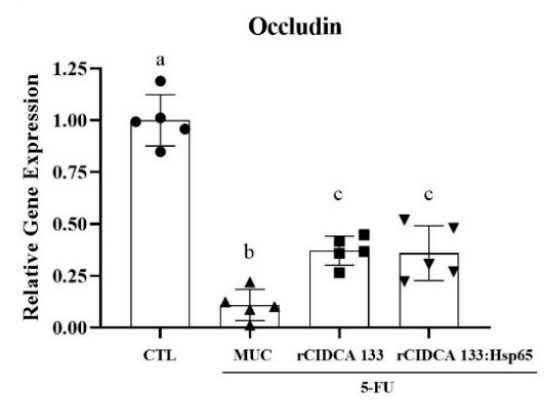

C)

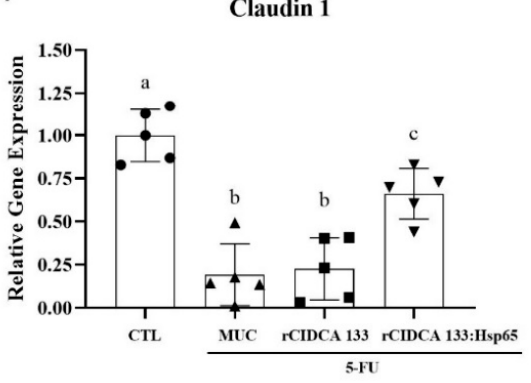

E)

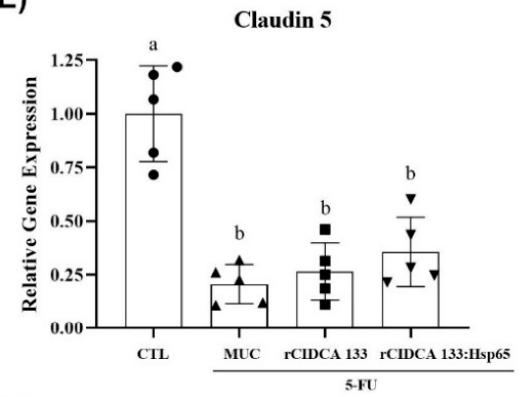

G)

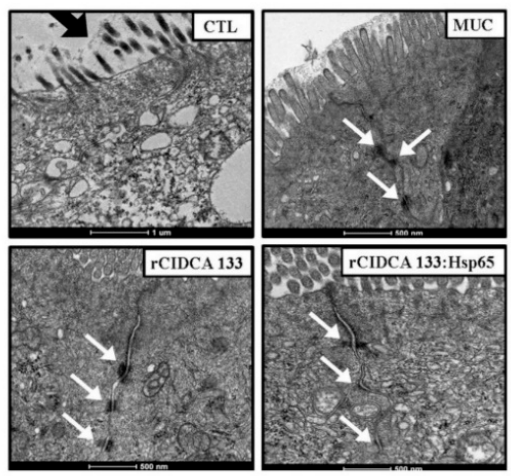

B)

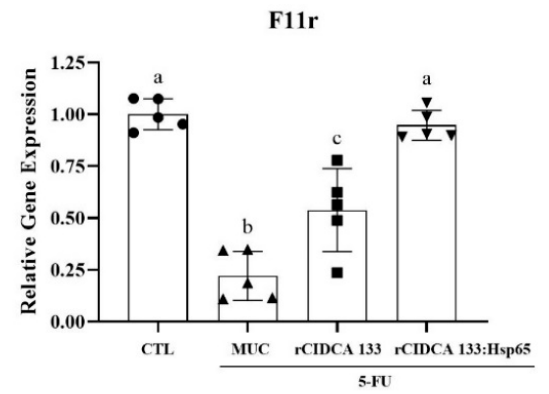

D)

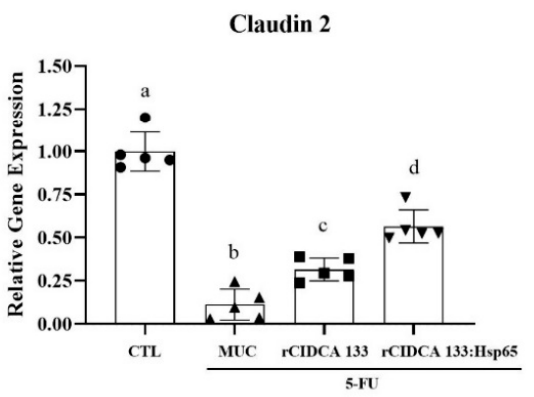

F)

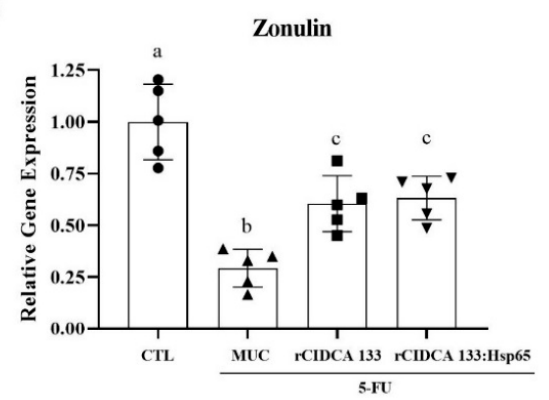

Figure 6. Level of relative mRNA expression of (A-F) tight junction proteins (occludin, F11r, claudin 1, claudin 2, claudin 5, and zonulin) determined by qPCR from animal ileum. Different letters (a-d) indicate statistically significant differences $(p<0.05)$ by ANOVA followed by the Bonferroni post hoc test $(\mathbf{A}-\mathbf{F})$. Geometric symbols show to the number of animals evaluated in each experimental group. $\bullet$ refers to the animals of CTL group, $\boldsymbol{\Delta}$ refers to the animals of MUC group, $\mathbf{\square}$ refers to the animals of rCIDCA 133 group and $\boldsymbol{\nabla}$ refers to the animals of rCIDCA 133:Hsp65 group. (G) Evaluation of cell junctions by transmission electron microscopy: dark arrow highlights the reduction in the number and length of microvilli of the MUC group cells compared to the other groups. The white arrows highlight desmosomes' presence at the lateral junctions between the epithelial cells in the CTL (scale $=1 \mu \mathrm{m})$, MUC, rCIDCA133, and rCIDCA 133:Hsp65 (scale = $500 \mathrm{~nm})$ groups. 
A)

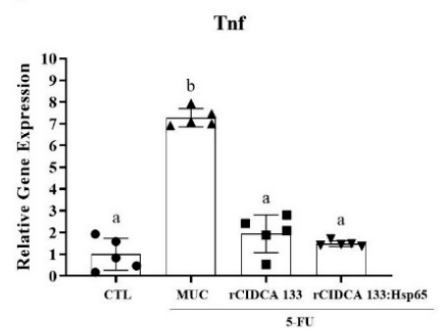

C)

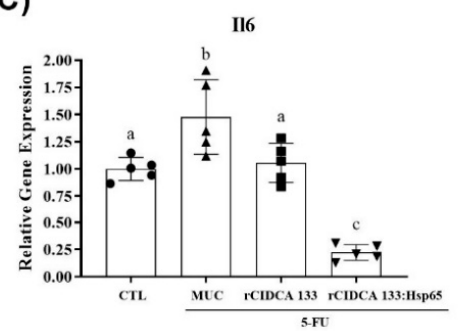

E)

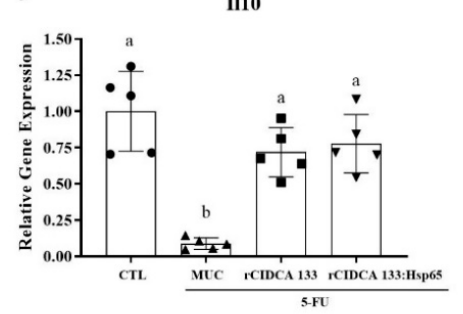

G)

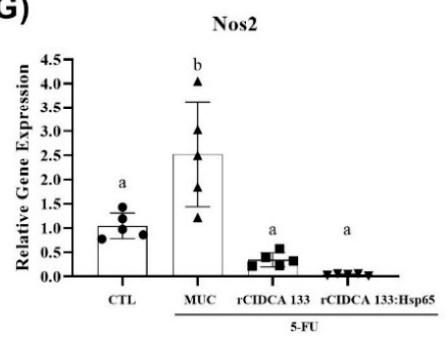

I)

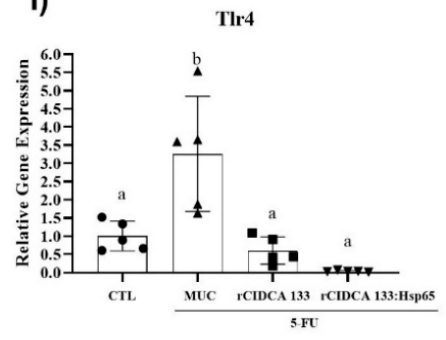

B)

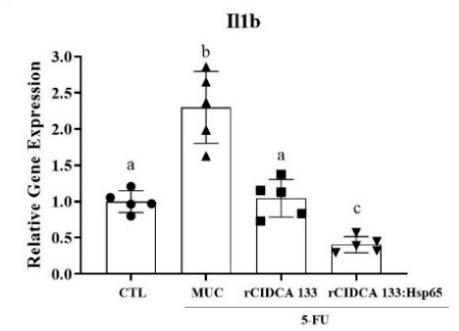

D)

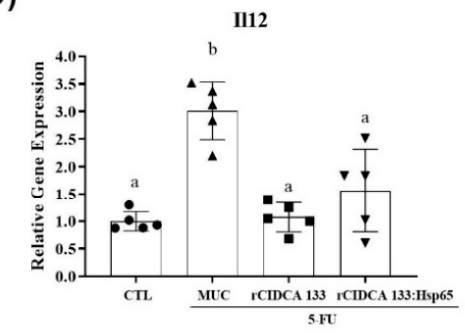

F)

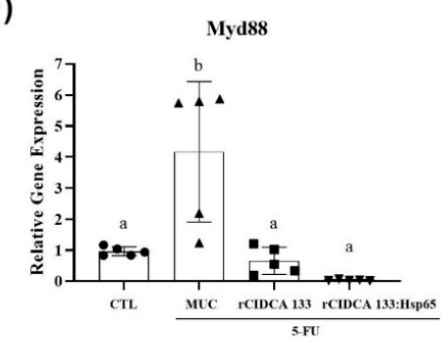

H)

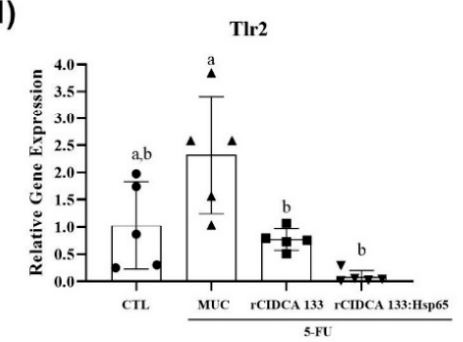

Figure 7. Relative gene expression of (A-I) Tnf, Il1b, Il6, Il12, Il10, Myd88, Nos2, Toll-like receptors 2 and 4. Mice received intraperitoneal 5-FU (300 mg/kg) (MUC, rCIDCA 133, and rCIDCA 133:Hsp65 groups) or saline solution (CTL group). They were treated with non-fermented milk supplemented with erythromycin 2.5\% (CTL and MUC) or recombinant $L$. delbrueckii CIDCA 133 (rCIDCA133 and rCIDCA133:Hsp65)-fermented milk supplemented with erythromycin $2.5 \%$ ( $n=5$ animals per group). Different letters indicate statistically significant differences $(p<0.05)$ by ANOVA followed by the Bonferroni post hoc test. Geometric symbols show to the number of animals evaluated in each experimental group. $\bullet$ refers to the animals of CTL group, $\boldsymbol{\Delta}$ refers to the animals of MUC group, $\boldsymbol{\square}$ refers to the animals of rCIDCA 133 group and $\mathbf{\nabla}$ refers to the animals of rCIDCA 133:Hsp65 group. 
3.8. Treatment with Recombinant Strains of Lactobacillus CIDCA 133 Reduces MYD88, NOS2, TLR2, and TLR4 Gene Expression

The MUC group showed a significant increase in mRNA expression of Myd88 (4.16 $\pm 2.26)$, Nos2 (2.52 \pm 1.090$)$, Tlr2 (2.32 \pm 1.08$)$, and Tlr4 (3.26 \pm 1.58$)$, when compared with the CTL group: Myd88 (1.00 \pm 0.14$)(p<0.001)$, Nos2 $(1.0 \pm 0.26)(p<0.001)$, Tlr2 $(1.0 \pm 0.79)(p<0.01)$, and Tlr4 $(1.0 \pm 0.40)(p<0.001)$. The treatment with the recombinant strains (rCIDCA 133 and rCIDCA 133:Hsp65) resulted in decreased Myd88 $(0.65 \pm 0.43$; $0.03 \pm 0.02)(p<0.001 ; p<0.0001)$, Nos2 $(0.34 \pm 0.14 ; 0.13 \pm 0.02)(p<0.0001)$, Tlr2 $(0.77 \pm 0.20 ; 0.08 \pm 0.11)(p<0.05 ; p<0.0001)$, and Tlr4 $(0.60 \pm 0.37 ; 0.03 \pm 0.01)(p<0.0001)$ gene expression. There were no statistical differences when these two recombinant groups were compared (Figure 7F-I).

\section{9. rCIDCA 133:Hsp65 Was Not Able to Reduce the Bacterial Translocation}

Bacterial translocation was evaluated $72 \mathrm{~h}$ after the induction of mucositis (Figure 8). Physiological levels of radiolabeled bacteria were detected in all organs, and blood was analyzed from the control group (CTL). This pattern was maintained in animals from the rCIDCA 133 group, except for liver and mesenteric lymph nodes, which were significantly different $(p<0.05)$. Increased amounts of $99 \mathrm{mTc}-E$. coli in the blood and all organs were observed in the 5-FU group, as expected. On the other hand, when organs of the rCIDCA: Hsp65 group were analyzed, it was possible to observe a high increment in radiolabeled bacteria. Only heart and kidney showed bacterial translocation similar to physiological levels $(p<0.05)$.

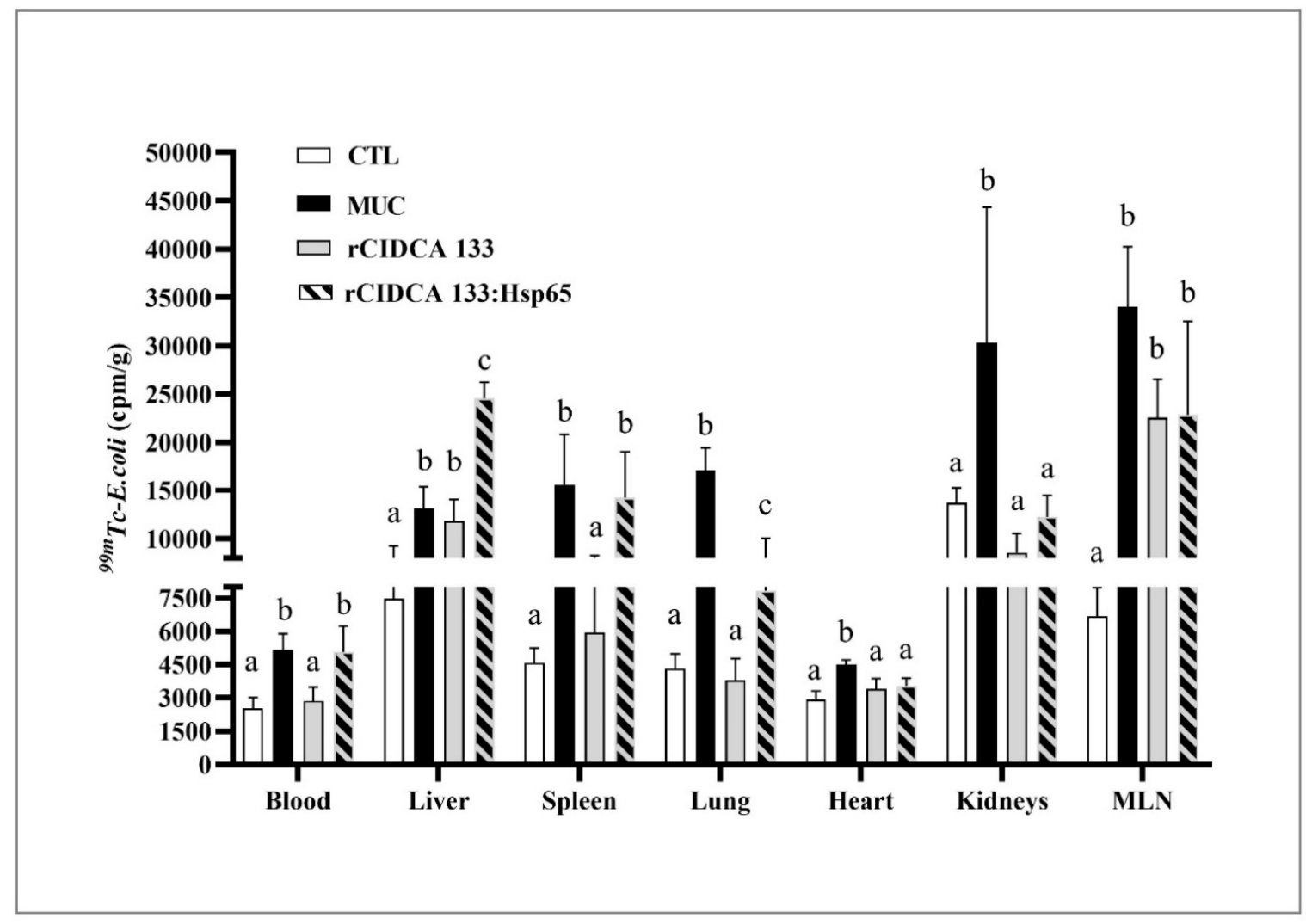

Figure 8. Biodistribution of 99mTc-Escherichia coli in animals with intestinal mucositis and treated with rCIDCA 133:Hsp65. cpm, counts per minute; MLN, mesenteric lymph node. Different letters indicate statistically significant differences $(p<0.05)$ by ANOVA followed by the Bonferroni post hoc test. 


\section{Discussion}

The Hsp65 protein has been intensely studied in different experimental models of inflammation. Studies were performed in a murine model of allergic airway inflammation and hyperresponsiveness to ovalbumin (OVA) (mice sensitized with OVA by i.p. injection and then challenged with OVA by inhalation) and reported that the intramuscular administration of Hsp65 from M. leprae before sensitization and challenge was able to prevent the development of these diseases. They reported reduced production of Il4 and Il5. They reported increased II10 and interferon-gamma (Ifng) in bronchoalveolar lavage fluid [63], with this attenuation effect being caused by Hsp65, acting on the modulation of dendritic cell function, as well as $\mathrm{CD} 4^{+} \mathrm{Th} 1$ cytokine production [64]. Other reports using oral pretreatment with recombinant L. lactis, which produces and secretes the Hsp65 protein (L. lactis (XIES:hsp65)) [48], showed promissory results: (i) an immunoregulatory effect exhibited by the reduction of pro-inflammatory cytokines (Ifng, Il6 and Tnf), as well as an increase in Il10 in colonic tissues and the expansion of $\mathrm{CD}^{+}{ }^{+} \mathrm{Foxp}^{+}$and $\mathrm{CD}^{+} \mathrm{LAP}^{+}$ regulatory $\mathrm{T}$ cells (Treg) in spleen and mesenteric lymph nodes, were able to prevent the Dextran Sulfate Sodium (DSS)-induced colitis in C57BL/6 mice [25] and (ii) prevention of the development of experimental autoimmune encephalomyelitis (EAE) in C57BL/6 mice by reduced inflammatory cell infiltrate and the absence of injury signs in the spinal cord with reduced Il17 and increased levels of Il10 in mesenteric lymph nodes and spleen cell cultures, and also an increase in natural and inducible regulatory $\mathrm{T}$ (Treg) cells [26]. Thus, all these findings indicate that Hsp65 from M. leprae has a potential therapeutic effect in many inflammation mouse models, and similar effects are shown in this study.

Consistent with this, we decided to develop a DNA vaccine using the pExu vector [49] for the host intestinal cells' local production of Hsp65 protein. After confirming the pExu:hsp65 vector's functionality in eukaryotic cells, the plasmid was transformed in the L. delbrueckii CIDCA 133 strain. This strain was isolated from raw cow milk [65] and has probiotic characteristics described as high resistance to acid $\mathrm{pH}$, bile salt, and entero-hemorrhagic microorganisms [65-67]. It can decrease harmful bacterial enzymatic activities [68] and resist antimicrobial peptides derived from enterocytes and human $\beta$ defensins $[69,70]$. This strain's capacity to stimulate phagocytosis by the induction of reactive oxygen species (ROS and NO) and promote the expression of surface markers related to antigen presentation in the in vitro test was described [71]. All these highlighted characteristics have encouraged us to test this strain in the mucositis inflammation model.

The protective effect of fermented milk by wild-type Lactobacillus delbrueckii subsp. lactis CIDCA 133 strain was previously tested for the first time by our research group in a mucositis mouse model [17]. In this experiment, mice received fermented milk for 13 days, and on the 10th day, they received the 5-FU drug to induce the mucositis. Animals treated with this strain presented a reduction in intestinal permeability values after the administration of 99mTc-DTPA by gavage. These animals also exhibited a preserved villus/crypt ratio, consequently showing a preserved epithelial architecture, with a significant amount of goblet cells and a reduction in inflammatory infiltrate. Altogether, this has shown the beneficial effect of this probiotic strain in intestinal inflammation, specifically in intestinal mucositis.

Therefore, combining the excellent reported characteristics of this probiotic strain with the benefits of the Hsp65 protein, we investigate the oral treatment capacity with recombinant $L$. delbrueckii CIDCA 133 (pExu:hsp65)-fermented milk in a mucositis mouse model.

In this work, mice who received treatment for 13 days with recombinant $L$. delbrueckii CIDCA 133 (pExu:hsp65)-fermented milk could avoid the intestinal shortening, reaching a length similar to the negative control. This parameter is very relevant to correlate the nutrient (food and liquid) uptake and the weight loss percentage, and consequently, the state of the animals' malnutrition. Thus, it was possible to attribute the lower weight loss to the group treated with L. delbrueckii CIDCA 133 (pExu:hsp65). According to a previous report, this effect was due to this bacteria's probiotic effect on the bowel's length [17]. 
Severe epithelial damage to the intestinal mucosa, especially in the jejunum and ileum sections, was related to mucositis pathobiology. Epithelial architecture and integrity damage with active migration of polymorphonuclear leukocytes (PMNs) stimulated by increased adhesion molecules from nuclear factor kappa B (NF-kB), through the intestinal villus and crypts, are typical signs of mucositis 1 . Thus, neutrophil infiltration has been described in several studies that assessed mucositis [17,53,72-75]. The beneficial effect of fermented milk by L. delbrueckii rCIDCA 133:Hsp65 on attenuating the intestinal inflammation was demonstrated by the decrease in MPO activity, the histological score with lower inflammatory infiltrate, and higher villus/crypt ratio. Additionally, the restoration of the epithelium's architecture was shown in this work, and the low histological score of these animals was the same as the negative control. Altogether, this denotes the beneficial effect of this treatment.

The beneficial effect of the treatment with L. delbrueckii rCIDCA 133:Hsp65 could also be observed in the increased number of goblet cells and the relative expression of the Muc2 gene. Mucins are secreted by the goblet cells and create a layer that protects the epithelium against bacterial penetration [76]. Thus, the higher number of these cells and also the level of expression of Muc2compared to the MUC group reinforce the positive effect of the recombinant treatment.

Secretory $\operatorname{Ig} \mathrm{A}$ is a primary immunologic component of the mucosal surface's extrinsic protective mechanism [77]. Our group's previous reports observed increased sIgA levels in the small bowel of inflamed groups $[17,22,78]$. This event is related to the intestinal inflammatory process of a host's defense mechanism [79]. However, other authors report a decrease in sIgA levels in inflamed groups [53,80], attributed to malnutrition generated by 5 FU reducing the sIgA responses and Gut-Associated Lymphoid Tissue (GALT) lymphocyte numbers. Following our previous reports, high levels of sIgA were observed in animals that did not receive any recombinant CIDCA 133 strain (MUC group), even more than in animals that received rCIDCA133:Hsp65.

On the other hand, the rCIDCA133 group manifested decreasing levels of this immunoglobulin. This immunoglobulin plays an essential role in different immune system functions and existing $\operatorname{IgA}$ antibodies with high and low affinity. Those with high affinity protect intestinal mucosal surfaces against invasion by pathogenic microorganisms, while low-affinity antibodies confine commensal bacteria to the intestinal lumen [81].

In healthy conditions, a small number of bacteria from the gut microbiota can translocate, and are killed during this passage or in the MLNs, a phenomenon that contributes to the maturation and maintenance of a competent gastrointestinal immune system [82-84]. In agreement with this affirmation, the CTL group showed a basal count of radioactivity in the blood and organs. Interestingly, animals treated with rCIDCA 133 only showed higher values of uptake of $99 \mathrm{mTc}-E$. coli in MLNs and liver and this event could be explained by gut injury or barrier failure contributing to the translocation of bacteria from the gut as MLNs are the first structures to receive the gut bacteria which, by portal circulation, reach the liver. This translocation pattern was demonstrated in other experimental models, which showed that viable bacteria could be found in the portal circulation, in high amounts, even before their appearance in intestinal lymph [85].

As the damage could be solved partially by rCIDCA 133, the other organs' translocation was the same as in the negative control, which presented the basal count of radioactivity.

Extremely high values of radioactivity were observed in the liver of animals that received rCIDCA133:Hsp65. These results could be attributed to the existence of the gut-liver axis, which is one of the most significant relations between gut microbiota and extraintestinal organs, representing an extremely close functional and bidirectional communication between these two organs [86]. Damage in the intestinal barrier automatically exposes the liver to bacterial components, such as pathogen-associated molecular patterns (PAMPs) and damage-associated molecular patterns (DAMPs), which could damage the organ by induction of an immune response, with the release of pro-inflammatory cytokines [87]. As the Hsp65 molecule has a dual role, inflammatory and regulatory, the liver's high inflammation 
due to the closer relationship with the gut was not enough to block the dissemination of $99 \mathrm{mTc}-E$. coli to the rest of the body. Additionally, as is often reported, the 5-FU cancer treatment generates a disruption of the indigenous microbiota's ecological balance and damage of the gut mucosal barrier by all the events involved in mucositis [88,89], which could lead to dysbiosis [90-92] with epithelium damage. The enteric venous system to the portal vein and the enteric lymphatic drainage are routes that could contribute to delivering bacteria or bacterial compounds from the gut to the circulation [93]. BT was the only parameter for which animals treated with rCIDCA133:Hsp65 did not show satisfactory results. These results can be explained, at least in part, by the fact that Hsps are closely related to apoptosis and ROS generation in human inflammatory diseases [94-96], and it is also known that oxidative stress metabolites can increase epithelial permeability [97]. Even though the treatment with recombinant bacteria has shown a reduction in the permeability, mucosal atrophy, mostly that associated with luminal nutrient deprivation, can be observed in mucositis, has been suggested as a predisposing factor for bacterial translocation [98]. Berg et al. [99] showed that immunosuppression associated with intestinal bacteria overgrowth promoted bacterial translocation in animals with histologically normal bowels. However, further studies must be performed to elucidate if this hypothesis can be applied to this specific mucositis model.

Moreover, two pathways could contribute to gastrointestinal permeability, the transcellular passage of molecules through the enterocytes using channels and membrane pumps, through the apical and basolateral membranes [100,101]. The paracellular route is regulated by tight junction proteins situated between adjacent enterocytes' apical lateral membranes, holding epithelial cells together. Their conservation and preservation are essential for cellular polarity and the intestinal epithelium's epithelial barrier function [93,102]. It is also known that tight junctions prevent the transepithelial movement of lipopolysaccharides and other macromolecules and bacteria [103].

The intestinal permeability was studied either by blood radioactivity after the oral intake of $99 \mathrm{mTc}$-DTPA or by relative mRNA expression of tight junction proteins. It was shown that these two approaches are related because an improvement in this parameter (IP) was observed. The percentage of doses/g of $99 \mathrm{mTc}$-DTPA was significantly lower in animals treated with recombinant strains. Treatment with the rCIDCA133:Hsp65 strain showed similar values to the negative control. Our results are in agreement with other reports where permeability was measured after probiotic treatment [17,53]. All the tight junction proteins studied, except claudin 5 , significantly increased the mRNA expression with recombinant treatment. When the mRNA expression of tight junctions in the ileum section was analyzed, an increase was observed. However, the gene expression of claudin 5 did not show increased mRNA expression.

However, the group treated with the milk fermented by rCIDCA133:Hsp65 showed a higher expression in F11r, claudin 1, and claudin 2, although occludin and zonulin did not show a difference between these two treatments, demonstrating that both recombinants strains were able to increase these relative tight junction expressions. The qPCR results were reinforced by transmission electronic microscopy analyses showing improved organization of zonula occludens, zonula adherents, desmosomes, and gap junctions in animals treated with the recombinant strains when compared to the ones of the positive control (MUC group). Altogether, these results show the relevant findings related to the intestinal permeability improvement after the fermented milk administration. These results agree with other reports showing the importance of probiotics in tight junction expression and, consequently, intestinal permeability [104-106].

There is a closer relation between intestinal tight junctions and cytokines' role under pathophysiological conditions. The disfunction of tight junctions mediated by cytokines leads to immune activation and tissue inflammation [107,108].

The exposition to cytotoxic therapy, such as 5-FU, leads to direct damage to cellular DNA, generating cell injury and death in both basal epithelium and submucosal cells and, consequently, increasing reactive oxygen species (ROS) [109]. They cause more severe 
damage to the involved tissues with macrophage stimulation and also activate the cascade of inflammatory pathways and transcription factors, such as NFKB 1 [110], which facilitates both the up-regulation of $111 \mathrm{~b}[111]$ and also the synthesis of pro-inflammatory molecules such as Tnf, Il6, cyclooxygenase-2 (Ptgs2), and Il12, among others [112,113].

In this study, the anti-inflammatory effect provided by both recombinant strains was shown. Milk fermented by both recombinant strains can attenuate the relative expression of the pro-inflammatory cytokines studied (Il1b, Il6, Il12, and Tnf), evidencing the antiinflammatory effect that these strains provide. The milk fermented by rCIDCA 133:Hsp65 was more effective in decreasing Il1b and Il6, leading to similar levels in the non-inflamed animals. The importance of these findings is due to the significant role in inflammation of both cytokines [114], participating as mediators in the course of intestinal apoptosis after 5-FU chemotherapy [115], and also causing an increase in intestinal permeability. Il1b and Tnf participate in amplifying the severity of chemotherapy-induced intestinal mucositis [1]. Tnf is relevant because it induces the activation and the recruitment of PMN cells, causing damage and intestinal barrier dysfunction, increasing the intestinal permeability, and, consequently, levels of pathogenic bacteria from the intestinal lumen [116,117]. Il6 production is a hallmark of many human chronic inflammatory states, including mucositis due to its pro-inflammatory properties $[118,119]$. It has a high level of participation in the inflammatory Tlr4-mediated pathway [120]. The basal levels of Tlr4 are fundamental to control physiological states and intestinal homeostasis [121]. Tlr4 knockout mice showed the importance of this pattern recognition receptor (PRR) in signaling through Myd88 of bacterial translocation [122]. This information could explain our results regarding the high level of translocation observed in animals treated with rCIDCA:Hsp65 since they presented much lower levels, even lower than the negative control, of Tlr4 and also Myd88 mRNA expression. However, further experiments should be performed to elucidate the mechanisms of this complex signaling pathway.

As 5-FU generates a dysbiosis in the bowel, disruption of the mucosal barrier upon injury to intestinal epithelial cells causes the exhibition of Tlr ligands by commensal bacteria to Tlr expressed in many bowel cells [123]. Thus, due to the significant role of the microbiota in intestinal inflammation, the active participation of Tlr in bacterial product recognition and its importance in inflammation induction encourages us to test the in vivo effect of Tlr ligation by commensal-derived products. Other essential intracellular adapters, such as Myd88 and Nod2, were also investigated. Tlrs (except Tlr3) stimulate the cells through Myd88, which mediates the early immune response to pathogens, leading to $\mathrm{Nf} \kappa \mathrm{b}$ translocation to the nucleus and, consequently, gene expression of encoded proinflammatory cytokines and chemotactic cytokines (chemokines) [124,125]. The microbial product also can be recognized by a family of intracellular signaling proteins, called Nod. They can detect microbial ligands in the cytosol. These cytosolic proteins signal $\mathrm{Nfkb}$ and MAPK, followed by the induction of numerous genes involved in the inflammatory process, thus triggering host innate immune responses [126-128]. Nod2 recognizes muramyl dipeptide on degraded bacterial cell wall peptidoglycan and can therefore respond to invading Gram-negative and Gram-positive bacteria.

Our results follow those of other authors who describe Tlrs as the major sensors of the innate immune system which recognize highly preserved motifs of microorganisms [129], and are related to the activation of signaling cascades, such as Nfkb, associated with inflammatory responses through the production of pro-inflammatory cytokines $[130,131]$. Additionally, an increase in the Tlr2 and Tlr4 levels was observed in animals that received 5-FU, and the administration of probiotics was able to reverse these increases [132], as we could demonstrate. This analysis shows, at least, a potential relationship between these parameters. However, mRNA expression cannot affirm that different circulant cytokines' different concentrations will be found due to the possible post-translational modification.

The Il10 cytokine is an important immunoregulatory molecule required to maintain immune homeostasis in the gut and contributes to declining inflammatory responses by down-regulating pro-inflammatory cytokine production at the site of tissue damage [133]. 
It is the most well-researched cytokine in inflammatory bowel disease (IBD), and its active form is secreted by different types of immune cells, such as Treg, monocytes, and macrophages $[134,135]$. Studies support the hypothesis that Il10 can attenuate Tnf receptor expression [136,137], which can be related to the results found in this study. In contrast, treatments with both recombinant strains were able to highly improve Il10 expression, with a reduction of Tnf, Il1b, and $\mathrm{Il} 6$ expression levels. These results are also supported by histological, MPO, and EPO analyses.

The results together show that animals undergoing induction chemotherapy with 5-FU and pretreated with L. delbrueckii CIDCA 133 (pExu:hsp65) experienced a reduced magnitude of damage to the mucosal architecture of the small intestine and decreased intestinal permeability, highlighting the importance that this probiotic recombinant strain has in reestablishing the number of goblet cells. Thus, the recombinant probiotic L. delbrueckii CIDCA 133 (pExu:hsp65) consumption could be an excellent alternative to ameliorating the intestinal damage caused by $5-F U$ in a mouse model.

Author Contributions: Conceptualization, F.A.L.B., and L.C.L.d.J.; Methodology, C.P.d.C., F.A.L.B., L.C.L.d.J., Ê.F., R.S.F., V.L.B., and A.L.B.d.B.; Investigation, P.M.-A., M.M.D., and S.Y.L.; WritingOriginal Draft, L.C.L.d.J., P.M.-A., and M.M.D.; Writing-Review and Editing, P.M.A., M.M.D., S.Y.L., A.L.B.d.B., and V.A.; Funding Acquisition, V.A.; Supervision, V.A. All authors have read and agreed to the published version of the manuscript.

Funding: This research was funded by Conselho Nacional de Desenvolvimento Científico e Tecnológico (CNPq), grant number 157371/2018-2 and 151578/2019-2.

Acknowledgments: This work was financially supported by grants from the Conselho Nacional de Desenvolvimento Científico e Tecnológico (CNPq), Coordenação de Aperfeiçoamento de Pessoal de Nível Superior (CAPES), and Fundação de Amparo à Pesquisa do Estado de Minas Gerais (FAPEMIG). The authors would like to acknowledge the Center of Microscopy at the Universidade Federal de Minas Gerais (http:/ / www.microscopia.ufmg.br) for providing the equipment and technical support for experiments involving electron microscopy and Centro Federal de Educação Tecnológica de Minas Gerais (CEFET/MG) for the support.

Conflicts of Interest: The authors declare no conflict of interest.

\section{References}

1. Sonis, S.T. The pathobiology of mucositis. Nat. Rev. Cancer 2004, 4, 277-284. [CrossRef] [PubMed]

2. Gifoni, M.; Lima, R.C.; Lima, A.A.M.; Facanha, A.; Callado, R.B.; Azevedo, C.; De Albuquerque Ribeiro, R. Clinical mucositis and intestinal permeability abnormalities in metastatic colorectal cancer patients treated with irinotecan and 5-fluoruracil. J. Clin. Oncol. 2012, 30, e14183. [CrossRef]

3. Chang, C.-T.; Ho, T.-Y.; Lin, H.; Liang, J.-A.; Huang, H.-C.; Li, C.-C.; Lo, H.-Y.; Wu, S.-L.; Huang, Y.-F.; Hsiang, C.-Y. 5-Fluorouracil Induced Intestinal Mucositis via Nuclear Factor- $\mathrm{B}$ B Activation by Transcriptomic Analysis and In Vivo Bioluminescence Imaging. PLoS ONE 2012, 7, e31808. [CrossRef] [PubMed]

4. Posner, M.R.; Haddad, R.I. Novel agents for the treatment of mucositis. J. Support. Oncol. 2007, 5, 33-39. [PubMed]

5. Nose, S.; Wasa, M.; Tazuke, Y.; Owari, M.; Fukuzawa, M. Cisplatin Upregulates Glutamine Transport in Human Intestinal Epithelial Cells. J. Parenter. Enter. Nutr. 2010, 34, 530-537. [CrossRef]

6. Bodiga, V.L.; Bodiga, S.; Surampudi, S.; Boindala, S.; Putcha, U.; Nagalla, B.; Subramaniam, K.; Manchala, R. Effect of vitamin supplementation on cisplatin-induced intestinal epithelial cell apoptosis in Wistar/NIN rats. Nutrition 2012, 28, 572-580. [CrossRef]

7. dos Santos Filho, E.X.; Ávila, P.H.M.; Bastos, C.C.C.; Batista, A.C.; Naves, L.N.; Marreto, R.N.; Lima, E.M.; Mendonça, E.F.; Valadares, M.C. Curcuminoids from Curcuma longa L. reduced intestinal mucositis induced by 5-fluorouracil in mice: Bioadhesive, proliferative, anti-inflammatory and antioxidant effects. Toxicol. Rep. 2016, 3, 55-62. [CrossRef]

8. Koppelmann, T.; Pollak, Y.; Mogilner, J.; Bejar, J.; Coran, A.G.; Sukhotnik, I. Reversal of severe methotrexate-induced intestinal damage using enteral n -3 fatty acids. Br. J. Nutr. 2013, 109, 89-98. [CrossRef]

9. Youmba, S.B.; Belmonte, L.; Galas, L.; Boukhettala, N.; Bôle-Feysot, C.; Déchelotte, P.; Coëffier, M. Methotrexate Modulates Tight Junctions Through NF-кB, MEK, and JNK Pathways. J. Pediatr. Gastroenterol. Nutr. 2012, 4, 463-470. [CrossRef]

10. Thomas, C.M.; Saulnier, D.M.A.; Spinler, J.K.; Hemarajata, P.; Gao, C.; Jones, S.E.; Grimm, A.; Balderas, M.A.; Burstein, M.D.; Morra, C.; et al. FolC2-mediated folate metabolism contributes to suppression of inflammation by probiotic Lactobacillus reuteri. Microbiologyopen 2016, 5, 802-818. [CrossRef] 
11. Whitford, E.J.; Cummins, A.G.; Butler, R.N.; Prisciandaro, L.D.; Fauser, J.K.; Yazbeck, R.; Lawrence, A.; Cheah, K.Y.; Wright, T.H.; Lymn, K.A.; et al. Effects of Streptococcus thermophilus TH-4 on intestinal mucositis induced by the chemotherapeutic agent 5-Fluorouracil (5-FU). Cancer Biol. Ther. 2009, 8, 505-511. [CrossRef] [PubMed]

12. Llewellyn, A.; Foey, A. Probiotic Modulation of Innate Cell Pathogen Sensing and Signaling Events. Nutrients 2017, 9, 1156. [CrossRef] [PubMed]

13. Lebeer, S.; Vanderleyden, J.; De Keersmaecker, S.C.J. Genes and Molecules of Lactobacilli Supporting Probiotic Action. Microbiol. Mol. Biol. Rev. 2008, 72, 728-764. [CrossRef] [PubMed]

14. Santos Rocha, C.; Lakhdari, O.; Blottière, H.M.; Blugeon, S.; Sokol, H.; Bermu'dez-Humara'n, L.G.; Azevedo, V.; Miyoshi, A.; Doré, J.; Langella, P.; et al. Anti-inflammatory properties of dairy lactobacilli. Inflamm. Bowel Dis. 2012, 18, 657-666. [CrossRef]

15. Luerce, T.; Gomes-Santos, A.; Rocha, C.; Moreira, T.; Cruz, D.; Lemos, L.; Sousa, A.; Pereira, V.; de Azevedo, M.; Moraes, K.; et al. Anti-inflammatory effects of Lactococcus lactis NCDO 2118 during the remission period of chemically induced colitis. Gut Pathog. 2014, 6, 33. [CrossRef]

16. Trindade, L.M.; Martins, V.D.; Rodrigues, N.M.; Souza, E.L.S.; Martins, F.S.; Costa, G.M.F.; Almeida-Leite, C.M.; Faria, A.M.C.; Cardoso, V.N.; Maioli, T.U.; et al. Oral administration of Simbioflora ${ }^{\circledR}$ (synbiotic) attenuates intestinal damage in a mouse model of 5-fluorouracil-induced mucositis. Benef. Microbes 2018, 9, 477-486. [CrossRef]

17. De Jesus, L.C.L.; Drumond, M.M.; de Carvalho, A.; Santos, S.S.; Martins, F.S.; Ferreira, Ê.; Fernandes, R.S.; de Barros, A.L.B.; do Carmo, F.L.R.; Perez, P.F.; et al. Protective effect of Lactobacillus delbrueckii subsp. Lactis CIDCA 133 in a model of 5 Fluorouracil-Induced intestinal mucositis. J. Funct. Foods 2019, 53, 197-207. [CrossRef]

18. Del Carmen, S.; Zurita-Turk, M.; Lima, F.A.; Dos Santos, J.S.C.; Leclercq, S.Y.; Chatel, J.-M.; Azevedo, V.; De Moreno De Leblanc, A.; Miyoshi, A.; Leblanc, J.G. A Novel Interleukin-10 Dna Mucosal Delivery System Attenuates Intestinal Inflammation in a Mouse Model. Eur. J. Inflamm. 2013, 11, 641-654. [CrossRef]

19. Zurita-Turk, M.; del Carmen, S.; Santos, A.C.; Pereira, V.B.; Cara, D.C.; Leclercq, S.Y.; de LeBlanc, A.dM.; Azevedo, V.; Chatel, J.-M.; LeBlanc, J.G.; et al. Lactococcus lactis carrying the pValac DNA expression vector coding for IL-10 reduces inflammation in a murine model of experimental colitis. BMC Biotechnol. 2014, 14, 73. [CrossRef]

20. Brash, A.R.; Boeglin, W.E.; Chang, M.S. Discovery of a second 15S-lipoxygenase in humans. Proc. Natl. Acad. Sci. USA 1997, 94, 6148-6152. [CrossRef]

21. Souza, B.M.; Preisser, T.M.; Pereira, V.B.; Zurita-Turk, M.; de Castro, C.P.; da Cunha, V.P.; de Oliveira, R.P.; Gomes-Santos, A.C.; de Faria, A.M.C.; Machado, D.C.C.; et al. Lactococcus lactis carrying the pValac eukaryotic expression vector coding for IL-4 reduces chemically-induced intestinal inflammation by increasing the levels of IL-10-producing regulatory cells. Microb. Cell Fact. 2016, 15, 150. [CrossRef] [PubMed]

22. Carvalho, R.D.; Breyner, N.; Menezes-Garcia, Z.; Rodrigues, N.M.; Lemos, L.; Maioli, T.U.; da Gloria Souza, D.; Carmona, D.; de Faria, A.M.C.; Langella, P.; et al. Secretion of biologically active pancreatitis-associated protein I (PAP) by genetically modified dairy Lactococcus lactis NZ9000 in the prevention of intestinal mucositis. Microb. Cell Fact. 2017, 16, 27. [CrossRef] [PubMed]

23. Doimo, N.T.; Zárate-Bladés, C.R.; Rodrigues, R.F.; Tefé-Silva, C.; Trotte, M.N.; Souza, P.R.; Soares, L.S.; Rios, W.M.; Floriano, E.M.; Brandão, I.T.; et al. Immunotherapy of tuberculosis with Mycobacterium leprae Hsp65 as a DNA vaccine triggers cross-reactive antibodies against mammalian Hsp60 but not pathological autoimmunity. Hum. Vaccin. Immunother. 2014, 10, 1238-1243. [CrossRef] [PubMed]

24. Herrera Ramírez, J.C.; De la Mora, A.C.; De la Mora Valle, A.; Lopez-Valencia, G.; Hurtado, R.M.B.; Rentería Evangelista, T.B.; Rodríguez Castillo, J.L.; Rodríguez Gardea, A.; Gómez Gómez, S.D.; Medina-Basulto, G.E. Immunopathological evaluation of recombinant mycobacterial antigen Hsp65 expressed in Lactococcus lactis as a novel vaccine candidate. Iran. J. Vet. Res. 2017, 18, 197-202.

25. Gomes-Santos, A.C.; de Oliveira, R.P.; Moreira, T.G.; Castro-Junior, A.B.; Horta, B.C.; Lemos, L.; de Almeida, L.A.; Rezende, R.M.; Cara, D.C.; Oliveira, S.C.; et al. Hsp65-Producing Lactococcus lactis Prevents Inflammatory Intestinal Disease in Mice by IL-10and TLR2-Dependent Pathways. Front. Immunol. 2017, 8. [CrossRef]

26. Rezende, R.M.; Oliveira, R.P.; Medeiros, S.R.; Gomes-Santos, A.C.; Alves, A.C.; Loli, F.G.; Guimarães, M.A.F.; Amaral, S.S.; da Cunha, A.P.; Weiner, H.L.; et al. Hsp65-producing Lactococcus lactis prevents experimental autoimmune encephalomyelitis in mice by inducing CD4+LAP+ regulatory T cells. J. Autoimmun. 2013, 40, 45-57. [CrossRef]

27. Baldon, E.; Marengo, E.; de Franco, M.; Starobinas, N.; Bueno, V.; Sant'Anna, O. Mycobacterium leprae Hsp65 administration reduces the lifespan of aged high antibody producer mice. Immun. Ageing 2014, 11, 6. [CrossRef]

28. Harats, D.; Yacov, N.; Gilburd, B.; Shoenfeld, Y.; George, J. Oral tolerance with heat shock protein 65 attenuates mycobacterium tuberculosis-inducedand high-fat-diet-driven atherosclerotic lesions. J. Am. Coll. Cardiol. 2002, 40, 1333-1338. [CrossRef]

29. Sakata, T.; Kojima, T.; Fujieda, M.; Miyakozawa, M.; Takahashi, M.; Ushida, K. Probiotic preparations dose-dependently increase net production rates of organic acids and decrease that of ammonia by pig cecal bacteria in batch culture. Dig. Dis. Sci. 1999, 44, 1485-1493. [CrossRef] [PubMed]

30. Walter, S. Structure and function of the GroE chaperone. Cell. Mol. Life Sci. 2002, 59, 1589-1597. [CrossRef] [PubMed]

31. Borges, J.C.; Ramos, C.H.I. Protein folding assisted by chaperones. Protein Pept. Lett. 2005, 12, 257-261. [CrossRef] [PubMed]

32. Hartl, F.U. Molecular chaperones in cellular protein folding. Nature 1996, 381, 571-580. [CrossRef] [PubMed]

33. Rothman, J.E. Polypeptide chain binding proteins: Catalysts of protein folding and related processes in cells. Cell 1989, 59, 591-601. [CrossRef] 
34. Mamalaki, C.; Murdjeva, M.; Tolaini, M.; Norton, T.; Chandler, P.; Townsend, A.; Simpson, E.; Kioussis, D. Tolerance in TCR/Cognate Antigen Double-Transgenic Mice Mediated by Incomplete Thymic Deletion and Peripheral Receptor Downregulation. Dev. Immunol. 1995, 4, 299-315. [CrossRef]

35. Bukau, B.; Horwich, A.L. The Hsp70 and Hsp60 Chaperone Machines. Cell 1998, 92, 351-366. [CrossRef]

36. Lindquist, S. The Heat-Shock Response. Annu. Rev. Biochem. 1986, 55, 1151-1191. [CrossRef] [PubMed]

37. Pockley, A.G. Heat shock proteins as regulators of the immune response. Lancet 2003, 362, 469-476. [CrossRef]

38. Saibil, H. Chaperone machines for protein folding, unfolding and disaggregation. Nat. Rev. Mol. Cell Biol. 2013, 14, 630-642. [CrossRef]

39. Lindquist, J.A. ER-60, a chaperone with thiol-dependent reductase activity involved in MHC class I assembly. EMBO J. 1998, 17, 2186-2195. [CrossRef]

40. Tsan, M.-F.; Gao, B. Heat shock proteins and immune system. J. Leukoc. Biol. 2009, 85, 905-910. [CrossRef]

41. Coelho, V.; Faria, A.M.C. HSP60: Issues and Insights on Its Therapeutic Use as an Immunoregulatory Agent. Front. Immunol. 2012, 2. [CrossRef] [PubMed]

42. Nishikawa, M.; Takemoto, S.; Takakura, Y. Heat shock protein derivatives for delivery of antigens to antigen presenting cells. Int. J. Pharm. 2008, 354, 23-27. [CrossRef] [PubMed]

43. Chun, J.N.; Choi, B.; Lee, K.W.; Lee, D.J.; Kang, D.H.; Lee, J.Y.; Song, I.S.; Kim, H.I.; Lee, S.-H.; Kim, H.S.; et al. Cytosolic Hsp60 Is Involved in the NF-KB-Dependent Survival of Cancer Cells via IKK Regulation. PLoS ONE 2010, 5, e9422. [CrossRef] [PubMed]

44. Lehner, T.; Bergmeier, L.A.; Wang, Y.; Tao, L.; Sing, M.; Spallek, R.; van der Zee, R. Heat shock proteins generate beta-chemokines which function as innate adjuvants enhancing adaptive immunity. Eur. J. Immunol. 2000, 30, 594-603. [CrossRef]

45. Moré, S.H.; Breloer, M.; von Bonin, A. Eukaryotic heat shock proteins as molecular links in innate and adaptive immune responses: Hsp60-mediated activation of cytotoxic T cells. Int. Immunol. 2001, 13, 1121-1127. [CrossRef] [PubMed]

46. Miao, J.; Niu, J.; Wang, K.; Xiao, Y.; Du, Y.; Zhou, L.; Duan, L.; Li, S.; Yang, G.; Chen, L.; et al. Heat Shock Factor 2 Levels Are Associated with the Severity of Ulcerative Colitis. PLoS ONE 2014, 9, e88822. [CrossRef] [PubMed]

47. Ciancio, M.J.; Chang, E.B. Do heat shock proteins play any role in gut inflammation? Inflamm. Bowel Dis. 2008, 14, S102-S103. [CrossRef]

48. de Azevedo, M.S.P.; Rocha, C.S.; Electo, N.; Pontes, D.S.; Molfetta, J.B.; Gonçalves, E.D.C.; Azevedo, V.; Silva, C.L.; Miyoshi, A. Cytoplasmic and extracellular expression of pharmaceutical-grade mycobacterial 65-kDa heat shock protein in Lactococcus lactis. Genet. Mol. Res. 2012, 11, 1146-1157. [CrossRef]

49. Mancha-Agresti, P.; Drumond, M.M.; do Carmo, F.L.R.; Santos, M.M.; dos Santos, J.S.C.; Venanzi, F.; Chatel, J.-M.; Leclercq, S.Y.; Azevedo, V. A New Broad Range Plasmid for DNA Delivery in Eukaryotic Cells Using Lactic Acid Bacteria: In Vitro and In Vivo Assays. Mol. Ther. Methods Clin. Dev. 2017, 4, 83-91. [CrossRef]

50. Pelizon, A.C.; Martins, D.R.; Zorzella-Pezavento, S.F.G.; Seger, J.; Justulin Jr, L.A.; da Fonseca, D.M.; Santos Jr, R.R.; Masson, A.P.; Silva, C.L.; Sartori, A. Neonatal BCG Immunization Followed by DNAhsp65 Boosters: Highly Immunogenic but not Protective Against Tuberculosis - a Paradoxical Effect of the Vector? Scand. J. Immunol. 2010, 71, 63-69. [CrossRef]

51. Green, M.R.; Hughes, H.; Sambrook, J.; MacCallum, P. Molecular Cloning: A Laboratory Manual, 4th ed.; Cold Spring Harbor: New York, NY, USA, 2012.

52. Coelho-Rocha, N.D.; de Castro, C.P.; de Jesus, L.C.L.; Leclercq, S.Y.; de Cicco Sandes, S.H.; Nunes, A.C.; Azevedo, V.; Drumond, M.M.; Mancha-Agresti, P. Microencapsulation of Lactic Acid Bacteria Improves the Gastrointestinal Delivery and in situ Expression of Recombinant Fluorescent Protein. Front. Microbiol. 2018, 9. [CrossRef]

53. de Barros, P.A.V.; Rabelo Andrade, M.E.; de Vasconcelos Generoso, S.; Mendes Miranda, S.E.; dos Reis, D.C.; Lacerda Leocádio, P.C.; de Sales e Souza, É.L.; dos Santos Martins, F.; da Gama, M.A.S.; Cassali, G.D.; et al. Conjugated linoleic acid prevents damage caused by intestinal mucositis induced by 5-fluorouracil in an experimental model. Biomed. Pharmacother. 2018, 103, 1567-1576. [CrossRef] [PubMed]

54. Diniz, S.O.; Resende, B.; Nunan, E.; Simal, C.J.; Cardoso, V. 99mTechnetium labelled Escherichia coli. Appl. Radiat. Isot. 1999, 51, 33-36. [CrossRef]

55. Soares, P.M.G.; Mota, J.M.S.C.; Gomes, A.S.; Oliveira, R.B.; Assreuy, A.M.S.; Brito, G.A.C.; Santos, A.A.; Ribeiro, R.A.; Souza, M.H.L.P. Gastrointestinal dysmotility in 5-fluorouracil-induced intestinal mucositis outlasts inflammatory process resolution. Cancer Chemother. Pharmacol. 2008, 63, 91-98. [CrossRef] [PubMed]

56. Bradley, P.P.; Priebat, D.A.; Christensen, R.D.; Rothstein, G. Measurement of Cutaneous Inflammation: Estimation of Neutrophil Content with an Enzyme Marker. J. Investig. Dermatol. 1982, 78, 206-209. [CrossRef] [PubMed]

57. Martins, F.S.; Silva, A.A.; Vieira, A.T.; Barbosa, F.H.F.; Arantes, R.M.E.; Teixeira, M.M.; Nicoli, J.R. Comparative study of Bifidobacterium animalis, Escherichia coli, Lactobacillus casei and Saccharomyces boulardii probiotic properties. Arch. Microbiol. 2009, 191, 623-630. [CrossRef]

58. Giulietti, A.; Overbergh, L.; Valckx, D.; Decallonne, B.; Bouillon, R.; Mathieu, C. An Overview of Real-Time Quantitative PCR: Applications to Quantify Cytokine Gene Expression. Methods 2001, 25, 386-401. [CrossRef]

59. Hellemans, J.; Mortier, G.; De Paepe, A.; Speleman, F.; Vandesompele, J. qBase relative quantification framework and software for management and automated analysis of real-time quantitative PCR data. Genome Biol. 2007, 8, R19. [CrossRef]

60. Volynets, V.; Rings, A.; Bárdos, G.; Ostaff, M.J.; Wehkamp, J.; Bischoff, S.C. Intestinal barrier analysis by assessment of mucins, tight junctions, and $\alpha$-defensins in healthy C57BL/6J and BALB/cJ mice. Tissue Barriers 2016, 4, e1208468. [CrossRef] 
61. Song, M.-K.; Park, M.-Y.; Sung, M.-K. 5-Fluorouracil-Induced Changes of Intestinal Integrity Biomarkers in BALB/C Mice. J. Cancer Prev. 2013, 18, 322-329. [CrossRef]

62. Chang, C.-W.; Lee, H.-C.; Li, L.-H.; Chiang Chiau, J.-S.; Wang, T.-E.; Chuang, W.-H.; Chen, M.-J.; Wang, H.-Y.; Shih, S.-C.; Liu, C.-Y.; et al. Fecal Microbiota Transplantation Prevents Intestinal Injury, Upregulation of Toll-Like Receptors, and 5Fluorouracil/Oxaliplatin-Induced Toxicity in Colorectal Cancer. Int. J. Mol. Sci. 2020, 21, 386. [CrossRef] [PubMed]

63. Rha, Y.-H.; Taube, C.; Haczku, A.; Joetham, A.; Takeda, K.; Duez, C.; Siegel, M.; Aydintug, M.K.; Born, W.K.; Dakhama, A.; et al. Effect of Microbial Heat Shock Proteins on Airway Inflammation and Hyperresponsiveness. J. Immunol. 2002, 169, 5300-5307. [CrossRef] [PubMed]

64. Shin, Y.S.; Takeda, K.; Shiraishi, Y.; Jeong, Y.Y.; Domenico, J.; Jia, Y.; Han, J.; Spallek, R.; Singh, M.; Lucas, J.J.; et al. Microbial Heat Shock Protein 65 Attenuates Airway Hyperresponsiveness and Inflammation by Modulating the Function of Dendritic Cells. J. Immunol. 2012, 189, 3404-3410. [CrossRef] [PubMed]

65. Kociubinski, G.L.; Pérez, P.F.; Añón, M.C.; DE Antoni, G.L. A Method of Screening for Highly Inhibitory Lactic Acid Bacteria. J. Food Prot. 1996, 59, 739-745. [CrossRef]

66. Kociubinski, G.; Pérez, P.; DE Antoni, G. Screening of Bile Resistance and Bile Precipitation in Lactic Acid Bacteria and Bifidobacteria. J. Food Prot. 1999, 62, 905-912. [CrossRef]

67. Hugo, A.A.; De Antoni, G.L.; Pérez, P.F. Lactobacillus delbrueckii subsp lactis strain CIDCA 133 inhibits nitrate reductase activity of Escherichia coli. Int. J. Food Microbiol. 2006, 111, 191-196. [CrossRef]

68. Hugo, A.A.; Kakisu, E.; De Antoni, G.L.; Pérez, P.F. Lactobacilli antagonize biological effects of enterohaemorrhagic Escherichia coli in vitro. Lett. Appl. Microbiol. 2008, 46, 613-619. [CrossRef]

69. Hugo, A.A.; De Antoni, G.L.; Pérez, P.F. Lactobacillus delbrueckii subsp lactis (strain CIDCA 133) resists the antimicrobial activity triggered by molecules derived from enterocyte-like Caco-2 cells. Lett. Appl. Microbiol. 2010, 50, 335-340. [CrossRef]

70. Hugo, A.A.; Tymczyszyn, E.E.; Gómez-Zavaglia, A.; Pérez, P.F. Effect of human defensins on lactobacilli and liposomes. J. Appl. Microbiol. 2012, 113, 1491-1497. [CrossRef]

71. Hugo, A.A.; Rolny, I.S.; Romanin, D.; Pérez, P.F. Lactobacillus delbrueckii subsp. lactis (strain CIDCA 133) stimulates murine macrophages infected with Citrobacter rodentium. World J. Microbiol. Biotechnol. 2017, 33, 48. [CrossRef]

72. Azevedo, O.G.R.; Oliveira, R.A.C.; Oliveira, B.C.; Zaja-Milatovic, S.; Araújo, C.V.; Wong, D.V.T.; Costa, T.B.; Lucena, H.B.M.; Lima-Júnior, R.C.P.; Ribeiro, R.A.; et al. Apolipoprotein E COG 133 mimetic peptide improves 5-fluorouracil-induced intestinal mucositis. BMC Gastroenterol. 2012, 12, 35. [CrossRef] [PubMed]

73. Ferreira, T.M.; Leonel, A.J.; Melo, M.A.; Santos, R.R.G.; Cara, D.C.; Cardoso, V.N.; Correia, M.I.T.D.; Alvarez-Leite, J.I. Oral Supplementation of Butyrate Reduces Mucositis and Intestinal Permeability Associated with 5-Fluorouracil Administration. Lipids 2012, 47, 669-678. [CrossRef] [PubMed]

74. Soares, P.M.G.; Mota, J.M.S.C.; Souza, E.P.; Justino, P.F.C.; Franco, A.X.; Cunha, F.Q.; Ribeiro, R.A.; Souza, M.H.L.P. Inflammatory intestinal damage induced by 5-fluorouracil requires IL-4. Cytokine 2013, 61, 46-49. [CrossRef] [PubMed]

75. Justino, P.F.C.; Melo, L.F.M.; Nogueira, A.F.; Costa, J.V.G.; Silva, L.M.N.; Santos, C.M.; Mendes, W.O.; Costa, M.R.; Franco, A.X.; Lima, A.A.; et al. Treatment with Saccharomyces boulardii reduces the inflammation and dysfunction of the gastrointestinal tract in 5-fluorouracil-induced intestinal mucositis in mice. Br. J. Nutr. 2014, 111, 1611-1621. [CrossRef] [PubMed]

76. Aranow, J.S.; Fink, M.P. Determinants of intestinal barrier failure in critical illness. Br. J. Anaesth. 1996, 77, 71-81. [CrossRef] [PubMed]

77. Macpherson, A.J.; McCoy, K.D.; Johansen, F.-E.; Brandtzaeg, P. The immune geography of IgA induction and function. Mucosal Immunol. 2008, 1, 11-22. [CrossRef]

78. Cordeiro, B.F.; Oliveira, E.R.; da Silva, S.H.; Savassi, B.M.; Acurcio, L.B.; Lemos, L.; de Alves, J.L.; Carvalho Assis, H.; Vieira, A.T.; Faria, A.M.C.; et al. Whey Protein Isolate-Supplemented Beverage, Fermented by Lactobacillus casei BL23 and Propionibacterium freudenreichii 138, in the Prevention of Mucositis in Mice. Front. Microbiol. 2018, 9. [CrossRef]

79. Schmucker, D.L.; Owen, R.L.; Outenreath, R.; Thoreux, K. Basis for the Age-related Decline in Intestinal Mucosal Immunity. Clin. Dev. Immunol. 2003, 10, 167-172. [CrossRef]

80. Nagayoshi, H.; Fukatsu, K.; Ueno, C.; Hara, E.; Maeshima, Y.; Omata, J.; Hiraide, H.; Mochizuki, H. 5-Fluorouracil Infusion Reduces Gut-Associated Lymphoid Tissue Cell Number and Mucosal Immunoglobulin A Levels. J. Parenter. Enter. Nutr. 2005, 29, 395-400. [CrossRef]

81. Lycke, N.Y.; Bemark, M. The regulation of gut mucosal IgA B-cell responses: Recent developments. Mucosal Immunol. 2017, 10, 1361-1374. [CrossRef]

82. Berg, R. Bacterial translocation from the gastrointestinal tract. Trends Microbiol. 1995, 3, 149-154. [CrossRef]

83. Lichtman, S.M. Baterial Translocation in Humans. J. Pediatr. Gastroenterol. Nutr. 2001, 33, 1-10. [CrossRef] [PubMed]

84. MacFie, J.; Reddy, B.S.; Gatt, M.; Jain, P.K.; Sowdi, R.; Mitchell, C.J. Bacterial translocation studied in 927 patients over 13 years. Br. J. Surg. 2006, 93, 87-93. [CrossRef] [PubMed]

85. Mainous, M.R. Studies of the Route, Magnitude, and Time Course of Bacterial Translocation in a Model of Systemic Inflammation. Arch. Surg. 1991, 126, 33. [CrossRef]

86. O'Hara, S.P.; Karlsen, T.H.; LaRusso, N.F. Cholangiocytes and the environment in primary sclerosing cholangitis: Where is the link? Gut 2017, 66, 1873-1877. [CrossRef] 
87. Brandl, K.; Kumar, V.; Eckmann, L. Gut-liver axis at the frontier of host-microbial interactions. Am. J. Physiol. Liver Physiol. 2017, 312, G413-G419. [CrossRef]

88. Stringer, A.M.; Gibson, R.J.; Logan, R.M.; Bowen, J.M.; Yeoh, A.S.J.; Hamilton, J.; Keefe, D.M.K. Gastrointestinal Microflora and Mucins May Play a Critical Role in the Development of 5-Fluorouracil-Induced Gastrointestinal Mucositis. Exp. Biol. Med. 2009, 234, 430-441. [CrossRef]

89. Carvalho, R.; Vaz, A.; Pereira, F.L.; Dorella, F.; Aguiar, E.; Chatel, J.-M.; Bermudez, L.; Langella, P.; Fernandes, G.; Figueiredo, H.; et al. Gut microbiome modulation during treatment of mucositis with the dairy bacterium Lactococcus lactis and recombinant strain secreting human antimicrobial PAP. Sci. Rep. 2018, 8, 15072. [CrossRef]

90. Ghoshal, U.C.; Shukla, R.; Ghoshal, U.; Gwee, K.-A.; Ng, S.C.; Quigley, E.M.M. The Gut Microbiota and Irritable Bowel Syndrome: Friend or Foe? Int. J. Inflam. 2012, 2012, 1-13. [CrossRef]

91. Manichanh, C.; Borruel, N.; Casellas, F.; Guarner, F. The gut microbiota in IBD. Nat. Rev. Gastroenterol. Hepatol. 2012, 9, 599-608. [CrossRef]

92. Stringer, A.M.; Al-Dasooqi, N.; Bowen, J.M.; Tan, T.H.; Radzuan, M.; Logan, R.M.; Mayo, B.; Keefe, D.M.K.; Gibson, R.J. Biomarkers of chemotherapy-induced diarrhoea: A clinical study of intestinal microbiome alterations, inflammation and circulating matrix metalloproteinases. Support. Care Cancer 2013, 21, 1843-1852. [CrossRef] [PubMed]

93. Vaishnavi, C. Translocation of gut flora and its role in sepsis. Indian J. Med. Microbiol. 2013, 31, 334. [CrossRef] [PubMed]

94. Beere, H.M. "The stress of dying": The role of heat shock proteins in the regulation of apoptosis. J. Cell Sci. 2004, 117, 2641-2651. [CrossRef] [PubMed]

95. van Eden, W.; van der Zee, R.; Prakken, B. Heat-shock proteins induce T-cell regulation of chronic inflammation. Nat. Rev. Immunol. 2005, 5, 318-330. [CrossRef] [PubMed]

96. Hauet-Broere, F.; Wieten, L.; Guichelaar, T.; Berlo, S.; van der Zee, R.; Van Eden, W. Heat shock proteins induce T cell regulation of chronic inflammation. Ann. Rheum. Dis. 2006, 65, iii65-iii68. [CrossRef]

97. Wilson, J.; Winter, M.; Shasby, D.M. Oxidants, ATP depletion, and endothelial permeability to macromolecules. Blood 1990, 76, 2578-2582. [CrossRef]

98. Choudhry, M.A.; Fazal, N.; Goto, M.; Gamelli, R.L.; Sayeed, M.M. Gut-associated lymphoid T cell suppression enhances bacterial translocation in alcohol and burn injury. Am. J. Physiol. Liver Physiol. 2002, 282, G937-G947. [CrossRef]

99. Berg, R.D. Immunosuppression and Intestinal Bacterial Overgrowth Synergistically Promote Bacterial Translocation. Arch. Surg. 1988, 123, 1359. [CrossRef]

100. MacFie, J. Current status of bacterial translocation as a cause of surgical sepsis. Br. Med. Bull. 2005, 71, 1-11. [CrossRef]

101. Wiest, R.; Lawson, M.; Geuking, M. Pathological bacterial translocation in liver cirrhosis. J. Hepatol. 2014, 60, 197-209. [CrossRef]

102. Andrade, M.E.R.; Araújo, R.S.; de Barros, P.A.V.; Soares, A.D.N.; Abrantes, F.A.; de Generoso, S.V.; Fernandes, S.O.A.; Cardoso, V.N. The role of immunomodulators on intestinal barrier homeostasis in experimental models. Clin. Nutr. 2015, 34, $1080-1087$. [CrossRef] [PubMed]

103. Alexander, J.W.; Boyce, S.T.; Babcock, G.F.; Gianotti, L.; Peck, M.D.; Dunn, D.L.; Pyles, T.; Childress, C.P.; Ash, S.K. The process of microbial translocation. Ann. Surg. 1990, 212, 496-510, discussion 511-512. [CrossRef] [PubMed]

104. Anderson, R.C.; Cookson, A.L.; McNabb, W.C.; Park, Z.; McCann, M.J.; Kelly, W.J.; Roy, N.C. Lactobacillus plantarum MB452 enhances the function of the intestinal barrier by increasing the expression levels of genes involved in tight junction formation. BMC Microbiol. 2010, 10, 316. [CrossRef]

105. Lépine, A.F.P.; de Wit, N.; Oosterink, E.; Wichers, H.; Mes, J.; de Vos, P. Lactobacillus acidophilus Attenuates Salmonella-Induced Stress of Epithelial Cells by Modulating Tight-Junction Genes and Cytokine Responses. Front. Microbiol. 2018, 9. [CrossRef]

106. Blackwood, B.P.; Yuan, C.Y.; Wood, D.R.; Nicolas, J.D.; Grothaus, J.S.; Hunter, C.J. Probiotic Lactobacillus Species Strengthen Intestinal Barrier Function and Tight Junction Integrity in Experimental Necrotizing Enterocolitis. J. Probiotics Heal. 2017, 5. [CrossRef] [PubMed]

107. Farhadi, A.; Banan, A.; Fields, J.; Keshavarzian, A. Intestinal barrier: An interface between health and disease. J. Gastroenterol. Hepatol. 2003, 18, 479-497. [CrossRef]

108. Turner, J.R. Intestinal mucosal barrier function in health and disease. Nat. Rev. Immunol. 2009, 9, 799-809. [CrossRef]

109. Logan, R.M.; Gibson, R.J.; Sonis, S.T.; Keefe, D.M.K. Nuclear factor-kB (NF- $\kappa B$ ) and cyclooxygenase-2 (COX-2) expression in the oral mucosa following cancer chemotherapy. Oral Oncol. 2007, 43, 395-401. [CrossRef] [PubMed]

110. Lawrence, T. The Nuclear Factor NF- B Pathway in Inflammation. Cold Spring Harb. Perspect. Biol. 2009, 1, a001651. [CrossRef]

111. Sultani, M.; Stringer, A.M.; Bowen, J.M.; Gibson, R.J. Anti-Inflammatory Cytokines: Important Immunoregulatory Factors Contributing to Chemotherapy-Induced Gastrointestinal Mucositis. Chemother. Res. Pract. 2012, 2012, 1-11. [CrossRef]

112. Hall, P.D.; Benko, H.; Hogan, K.R.; Stuart, R.K. The influence of serum tumor necrosis factor-alpha and interleukin-6 concentrations on nonhematologic toxicity and hematologic recovery in patients with acute myelogenous leukemia. Exp. Hematol. 1995, 23, 1256-1260. [PubMed]

113. Sonis, S. Pathobiology of oral mucositis: Novel insights and opportunities. J. Support. Oncol. 2007, 5, 3-11. [PubMed]

114. Dinarello, C.A. A clinical perspective of IL-1 $\beta$ as the gatekeeper of inflammation. Eur. J. Immunol. 2011, 41, 1203-1217. [CrossRef] [PubMed] 
115. Wu, Z.-Q.; Han, X.-D.; Wang, Y.; Yuan, K.-L.; Jin, Z.-M.; Di, J.-Z.; Yan, J.; Pan, Y.; Zhang, P.; Huang, X.-Y.; et al. Interleukin-1 receptor antagonist reduced apoptosis and attenuated intestinal mucositis in a 5-fluorouracil chemotherapy model in mice. Cancer Chemother. Pharmacol. 2011, 68, 87-96. [CrossRef]

116. Turner, J.R. Molecular Basis of Epithelial Barrier Regulation. Am. J. Pathol. 2006, 169, 1901-1909. [CrossRef]

117. Suzuki, T. Regulation of intestinal epithelial permeability by tight junctions. Cell. Mol. Life Sci. 2013, 70, 631-659. [CrossRef]

118. Logan, R.M.; Stringer, A.M.; Bowen, J.M.; Yeoh, A.S.-J.; Gibson, R.J.; Sonis, S.T.; Keefe, D.M.K. The role of pro-inflammatory cytokines in cancer treatment-induced alimentary tract mucositis: Pathobiology, animal models and cytotoxic drugs. Cancer Treat. Rev. 2007, 33, 448-460. [CrossRef]

119. Logan, R.M.; Gibson, R.J.; Bowen, J.M.; Stringer, A.M.; Sonis, S.T.; Keefe, D.M.K. Characterisation of mucosal changes in the alimentary tract following administration of irinotecan: Implications for the pathobiology of mucositis. Cancer Chemother. Pharmacol. 2008, 62, 33-41. [CrossRef] [PubMed]

120. Greenhill, C.J.; Rose-John, S.; Lissilaa, R.; Ferlin, W.; Ernst, M.; Hertzog, P.J.; Mansell, A.; Jenkins, B.J. IL-6 Trans -Signaling Modulates TLR4-Dependent Inflammatory Responses via STAT3. J. Immunol. 2011, 186, 1199-1208. [CrossRef]

121. Cario, E. Toll-like receptors in the pathogenesis of chemotherapy-induced gastrointestinal toxicity. Curr. Opin. Support. Palliat. Care 2016, 10, 157-164. [CrossRef]

122. Fukata, M.; Michelsen, K.S.; Eri, R.; Thomas, L.S.; Hu, B.; Lukasek, K.; Nast, C.C.; Lechago, J.; Xu, R.; Naiki, Y.; et al. Toll-like receptor- 4 is required for intestinal response to epithelial injury and limiting bacterial translocation in a murine model of acute colitis. Am. J. Physiol. Liver Physiol. 2005, 288, G1055-G1065. [CrossRef] [PubMed]

123. Strober, W.; Fuss, I.J.; Blumberg, R.S. The immunology of mucosal models of inflammation. Annu. Rev. Immunol. 2002, 20, 495-549. [CrossRef] [PubMed]

124. Takeda, K.; Kaisho, T.; Akira, S. Toll-like receptors. Annu. Rev. Immunol. 2003, 21, 335-376. [CrossRef] [PubMed]

125. O'Neill, L.A.J.; Golenbock, D.; Bowie, A.G. The history of Toll-like receptors-Redefining innate immunity. Nat. Rev. Immunol. 2013, 13, 453-460. [CrossRef] [PubMed]

126. Inohara, N. An induced proximity model for NF-kappaB activation in the Nod1/RICK and RIP signaling pathways. J. Biol. Chem. 2000. [CrossRef] [PubMed]

127. Ogura, Y.; Bonen, D.K.; Inohara, N.; Nicolae, D.L.; Chen, F.F.; Ramos, R.; Britton, H.; Moran, T.; Karaliuskas, R.; Duerr, R.H.; et al. A frameshift mutation in NOD2 associated with susceptibility to Crohn's disease. Nature 2001, 411, 603-606. [CrossRef] [PubMed]

128. Hayden, M.S. Signaling to NF- B. Genes Dev. 2004, 18, 2195-2224. [CrossRef]

129. Cario, E.; Gerken, G.; Podolsky, D.K. Toll-like receptor 2 enhances ZO-1-associated intestinal epithelial barrier integrity via protein kinase C. Gastroenterology 2004, 127, 224-238. [CrossRef]

130. Vijay-Kumar, M.; Sanders, C.J.; Taylor, R.T.; Kumar, A.; Aitken, J.D.; Sitaraman, S.V.; Neish, A.S.; Uematsu, S.; Akira, S.; Williams, I.R.; et al. Deletion of TLR5 results in spontaneous colitis in mice. J. Clin. Investig. 2007. [CrossRef]

131. Ahrne, S.; Johansson Hagslatt, M.-L. Effect of Lactobacilli on Paracellular Permeability in the Gut. Nutrients 2011, 3, $104-117$. [CrossRef]

132. Tang, Y.; Wu, Y.; Huang, Z.; Dong, W.; Deng, Y.; Wang, F.; Li, M.; Yuan, J. Administration of probiotic mixture DM\#1 ameliorated 5-fluorouracil-induced intestinal mucositis and dysbiosis in rats. Nutrition 2017, 33, 96-104. [CrossRef]

133. Rubtsov, Y.P.; Rasmussen, J.P.; Chi, E.Y.; Fontenot, J.; Castelli, L.; Ye, X.; Treuting, P.; Siewe, L.; Roers, A.; Henderson, W.R.; et al. Regulatory T Cell-Derived Interleukin-10 Limits Inflammation at Environmental Interfaces. Immunity 2008, $28,546-558$. [CrossRef] [PubMed]

134. Lacki, J.K.; Wiktorowicz, K.E. Biological properties of interleukin 10. Postepy Hig. Med. Dosw. 1994, 48, 363-370. [PubMed]

135. Asadullah, K.; Sterry, W.; Volk, H.D. Interleukin-10 Therapy-Review of a New Approach. Pharmacol. Rev. 2003, 55, 241-269. [CrossRef] [PubMed]

136. Gérard, C.; Bruyns, C.; Marchant, A.; Abramowicz, D.; Vandenabeele, P.; Delvaux, A.; Fiers, W.; Goldman, M.; Velu, T. Interleukin 10 reduces the release of tumor necrosis factor and prevents lethality in experimental endotoxemia. J. Exp. Med. 1993, 177, 547-550. [CrossRef]

137. Clarke, C.J.P.; Hales, A.; Hunt, A.; Foxwell, B.M.J. IL-10-mediated suppression of TNF- $\alpha$ production is independent of its ability to inhibit NFkB activity. Eur. J. Immunol. 1998, 28, 1719-1726. [CrossRef] 